Espacio. Tiempo y Forma, Serie VII, $H^{a}{ }^{a}$ del Arte, t. 10, 1997, págs. 59-110

\title{
Perfil del joyero
}

\author{
M. a TeResa JIMÉnez Priego
}

\section{RESUMEN ABSTRACT}

El concepto básico de joyero 10 circunscribimos al artesano que fabrica joyas y no al vendedor. Hacemos una profundización en la etimología de la palabra y los diferentes términos, con los cuales, a pesar de su diferenciación, se le ha identificado a través del tiempo.

Las líneas esenciales de la exposición vienen marcadas por las cualidades que constituyen la personalidad de este artista: su carácter moral de probidad y trabajo, su adecuada formación en talleres, el profundo conocimiento de materiales y técnicas, aunado a una habilidad y adiestramiento manual.

La perfección y reducidas dimensiones de los objetos que crea le exigen la experiencia de las propiedades del oro, plata, platino, piedras preciosas y perlas, asi como el tratamiento de los mismos con las técnicas más
The basic concept of jeweller is not referred to the seller, but to the craftsman who makes jewels. We study deeply the etymology of the word jeweller, as well as the different terms with which, although they are different, the jeweller has been identified throughout the years.

The main outlines of this article are determined by the qualities of these craftsmans' personality: their moral character of probity and work, their adequate training in workshops, their deep knowledge of techniques and materials, as well as, their manual training and ability.

The perfection and reduced dimensions of the objects they create, require them to have experienced the properties of gold, silver, platinum, precious stones and pearls, as well as the treatment of these materials with

* Departamento de Historia del Arte. UNED. 
adecuadas -engastado. martillado. grabado...-, empleando un utillaje especifico.

El desarrollo y perfección de este arte llevaron al joyero a agruparse en cofradias gremios y colegios, que controlaban y favorecian la actividad de este sector.

Este estudio pretende ser global y analitico. abarcando la evolución de este artesano a través de la historia. the most suitable techniques - such as, setting, hammering engraving...-. by using specific tools.

The development and perfection of this art led the jewellers to group in brotherhoods, guilds and colleges. which controlled and encouraged this sector's activity.

This article intends to be global and analytic. by studying the evolution of this craftsman's profile throughout history.

El joyero nunca ha sido tan animoso para el buen decir, como presto para el buen hacer.

B. Cellini

El joyero ejerce una profesión artística que exige esencialmente cualida des de inteligencia. gusto y destreza manual. Benvenuto Cellini abunda en esta idea, al justificar el arte de la orfebrería como una técnica dificultosa y no al alcance de todos. añadiendo que esta complejidad técnica no sólo se ha de alcanzar mediante la práctica. sino a través del pensamiento y la idea.

En la joya, sea de oro o de piedras preciosas, se estima, primeramente su valor artístico, después sus materiales y, finalmente. el elemento más importante: la perfección de la ejecución material. Es lo que, lapidariamente. el abad Suger hizo inscribir en la puerta del templo de Saint Denis :

"si quieres exaltar la gloria de estas puertas no te maravilles por el oro.. sino por la maestria del trabajo".

Generalmente. se asocian los términos orfebre. platero y joyero. en español. asi como "bijoutier" y "joaillier" o l'orfèvre bijoutier y l'orfèvre juaillier. en francés. Estas artes se amalgaman hasta el punto de ser sólo una, pero las evoluciones técnicas, la especialización -esta tendencia de

Brnvt nillo Chilnt. Tratados de orfebreria escultura, dibujo y arquitectura. Traducción de Juan Calatrava Escobar y prólogo de Fernando Checa Cremades. Madrid. Akal. 1989 (Ed de Florencia. 1568) pags 12-17 y 23-24

Liber de rebus in adminsitratione sua gestis. 1.144-1.145. Ms. lat. 13835 de la Bibl. Nat. de Paris. Citado en Arte Medieval II. Romanico y Gotico Fuentes y Documentos para la Historia del Arte Barcelona. 1982. págs. 33-34 
nuestra civilización-, la búsqueda de otros fines nos llevan a distinguir al joyero del platero, o al "bijoutier» del «joaillier», en su caso, aunque los dos fabriquen objetos de adorno.

Se trata de nombres que se remontan a la época medieval y a la posterior evolución de los gremios, cuando en un mismo taller se trabajaban todas las especialidades que, ya de forma individual o por separado, se daban en una misma obra. En cada caso, el prefijo puede ayudarnos a entender el contenido y el alcance profesional del sector aludido: orfebre sería el que trabaja y vende objetos de oro; platero el que trabaja y vende objetos de plata; y joyero el que se dedica a fabricar o vender joyas, sean de la materia prima que sean, aunque, preferentemente, de oro o plata ${ }^{3}$. En la práctica, sin embargo, se emplean cada una de estas denominaciones sin delimitar las etimologías, lo cual dificulta la clasificación de los oficios y de sus diferentes especialidades.

Las palabras de mayor tradición son las de platero y joyero, ya que asi se denominaban nuestros gremios y así se conocia, todavía a principios de siglo, la asociación artística que tantos éxitos profesionales obtuvo.

Según la Enciclopedia Francesa ${ }^{4}$, el orfebre es un artista fabricante y comerciante a la vez.... que tiene la facultad de vender, comprar y fabricar toda suerte de vajilla, obras y joyas de oro y plata. El término orfebre tiene su etimología en el latín: auri faber, fabricante en oro. Según la Enciclopedia, los orfebres se denominan orfebres, joyeros, bisuteros. Se entiende, comúnmente, por orfebre simple, el que sólo se ocupa de fabricar o vender vajilla de plata. Orfebre-joyero es aquél, que bien vende o fabrica joyas de oro. El orfebre-joyero-engastador vende y engasta diamantes, perlas y piedras preciosas. Nosotros daremos ambos términos, aunque estudiamos el joyero.

Entre los conocimientos que deben tener estos profesionales se incluyen ciertas operaciones mecánicas, que denotan el gusto del artista y su genio creativo, como el cincelado, grabado, repujado, (figs. 1 a y b), etc. Conviene también que sean instruidos en el estudio de la metalurgia y la pág. 5 .

Nuria Dalmases y Daniel Giral t-MiRacle, Plateros y joyeros de Cataluña. Barcelona, 1985

DIIF ROT et D AIF MBE RT, L Encyclopédie ou Dictionnaire raisonné des sciences, des arts et des métiers. París, 1751-1780. "Recueil de planches, sur les sciences, les arts libéraux et les arts mécaniques avec leur explication. Orfèvrerie-Joaillerie". Este "Recueil" ha sido traducido por primera vez al español por Luis Montañés, en la Rev. Iberjoya, en 1982 


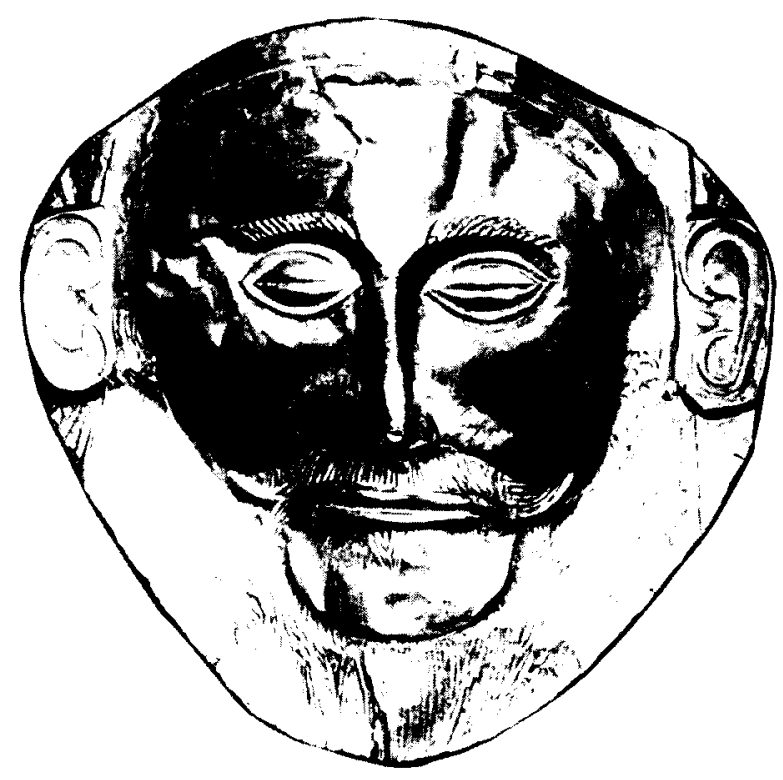

Fig. 1a. Máscara de Agamenón. De oro repujado. Museo Arqueológico Nacional de Atenas.

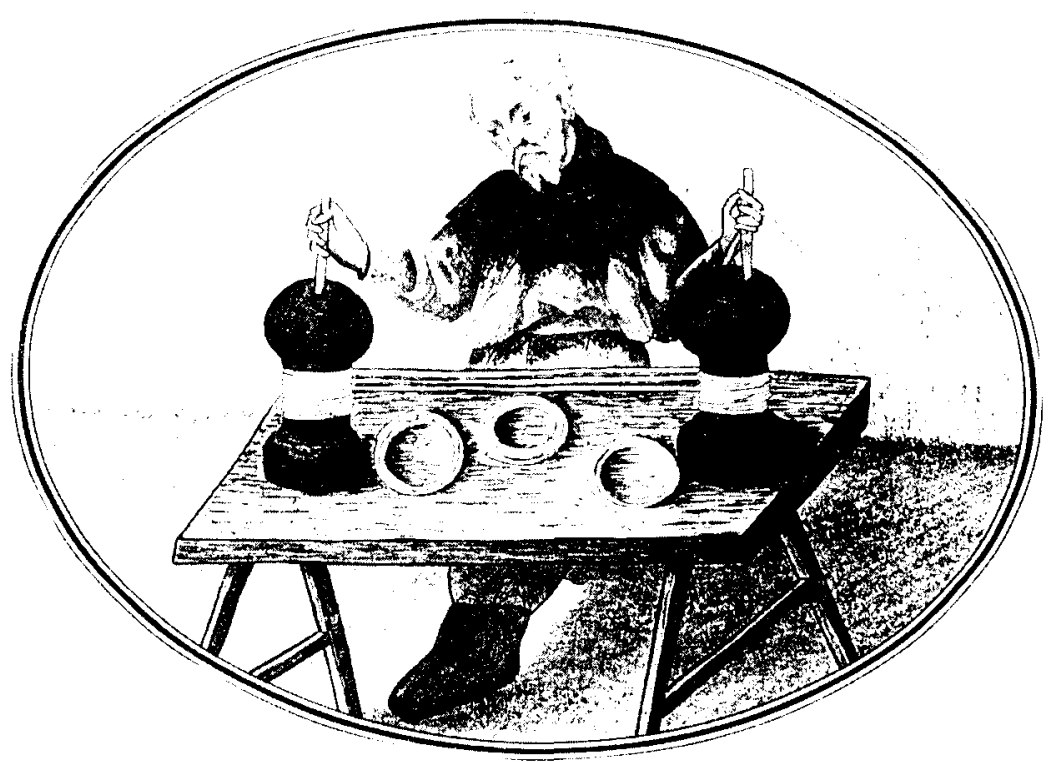

Fig. 1b. Joyero fabricando los hilos de oro. 
docimasia, ciencias que les enseñan el arte de preparar el oro y la plata, alterando la pureza y ductilidad que les es propia ${ }^{5}$.

\section{DE LA PREHISTORIA A LOS ROMANOS}

Teniendo en cuenta que en los comienzos de la metalurgia, no se consideraba el trabajo del oro como una especialidad independiente de la del trabajo del cobre o del bronce, o ni siquiera como una actividad a tiempo completo, resultaría muy difícil identificar un hipotético taller de joyería. Sin embargo, se pueden dar unos conceptos que definen la tradición artesanal de aquellos posibles "talleres" desde la época prehistórica.

Los elementos constitutivos de un taller serian: un conjunto de obras que, por su carácter tipológico, técnico y decorativo, pueden ser representativas del mismo y en las que tiene importancia fundamental el contexto histórico cultural del entorno. Por ejemplo, en la Península Ibérica, previamente a su romanización, se conocía el trabajo del oro desde el Calcolítico hasta la Edad del Bronce ${ }^{6}$.

Las leyendas transmitidas por los griegos nos revelan la antigüedad del trabajo del metal. En efecto, los griegos atribuian a unos pueblos legendarios la invención de la metalurgia y del trabajo del oro que, en un principio, no se puede disociar del del bronce. Es significativo que estos pueblos sean extranjeros a la misma Grecia ? . Entre ellos cabe enumerar a los Calybes, situados en el Cáucaso o en el Ponto. Arimaspes, habitantes de las regiones escitas, usurpadores del oro de las minas. Dactydes, enanos metalurgistas que extraian el hierro y el oro de las laderas del Monte Ida. Igualmente, las figuras heroicas del hierro y de la forja - Prometeo, Hefaistos, Vulcano, Gilgamés- en Mesopotamia, son testimonios de un estado social desaparecido en la época histórica, en el seno de la cual el herrero y el orfebre, que se confunde con él, practican cultos particulares y gozan de un prestigio especial, de una situación autónoma en la tribu, cuya actividad principal es la agricultura.

Fonit Nar. Eugène, Les Bijoux anciens et modernes. Paris, Quantin, 1887. págs. 10-15. 477 y ss. TILMANS. Emile, Le bijou. Paris, Flammarion, 1961, pág. 5.

Alicia PtreA, "Les premiers atelier d'ortèvre dans la Péninsule Ibérique» en Outils et ateliers dorfèvres de temps anciens. Société des Amis du Musée des Antiquités Nationales et du Château de Saint-Geramain-in-Laye, 1993, págs. 23-28

Étienne Cocht DE I A FtRIE, Le bijoux antiques, Paris, 1956, pág. 3. 
Al parecer, es probable que los orfebres, o al menos los herreros, constituyeran, en su origen, un grupo de individuos independientes, y, hasta podía creerse, procedentes de una raza especial. Se ha podido probar, por ejemplo, que, en el Egipto prehistórico y aún en el Imperio Antiguo, los orfebres eran de origen pigmeo.

Gracias a unas inscripciones funerarias conocemos la existencia de gildas de joyeros en Italia, en la época histórica. Sabemos, también, por Plutarco ${ }^{8}$, que Numa, uno de los reyes de Roma, había incluido a los orfebres en las corporaciones de oficios entre las que él dividió el pueblo romano para asegurar su unidad.

Agrupados cerca del Foro, los orfebres, que pertenecian a la asociación, como ciudadanos libres, sufrian una dura competencia por parte de los esclavos especializados que trabajaban por cuenta exclusiva de un patrón, emperador o rico patricio. Si los orfebres romanos habitaban el Foro, hay que pensar que los joyeros atenienses, paralelamente, habitaron el Agora. Demóstenes ${ }^{9}$ nos habla de un orfebre cuya boutique (chrysochoéion) estaba situada sobre el Agora. Sin duda, existieron en Grecia cotradias análogas a las de Roma.

Los griegos llamaron al joyero chrysochóos, es decir, aquél que funde el oro. Los romanos lo denominaron aurifex, el que lo trabaja, o bractearius, el que lo transforma en hojas. Es una idea análoga que se encuentra aún en la expresión empleada por Plutarco ${ }^{10}$, cuando cita, entre los obreros que emplea Pericles para sus grandes trabajos destinados a embellecer Atenas, a los chrysou malakteres, los que ablandan el oro (fig. 2).

Estas expresiones se explican por el hecho de que, si los primeros trabajos fueron hechos con el martillo sobre el oro maleable de las pepitas, se adoptó sin duda rápidamente -antes de la formacićn del vocabulario técnico griego, en todo caso- el hábito de verter en el molde las pepitas para formar con ellas unos lingotes. Esta operación tan simple no debe ser confundida con la fundición, propiamente dicha, que se utiliza para purificar el mineral, para obtener aleaciones, etc., y que no apareció sino más tarde. Otros términos sirven aún para designar a los joyeros griegos o romanos, enfatizando una u otra fase del trabajo - martillado y fundición-.

Vidas paralelas. Vida de Numa, 17. "Distribución de la plebe por oficios", Introducción, traducción y notas por Aurelio Pérez Jiménez. Madrid, 1985.

Demostenes, Contra Midias, Against Meidias. Oxford, 1990, 22, pág. 103.

Vidas paralelas. Vida de Pericles, 12, "Las grandes realizaciones artísticas durante el go. bierno de Pericles". Madrid, 1961 


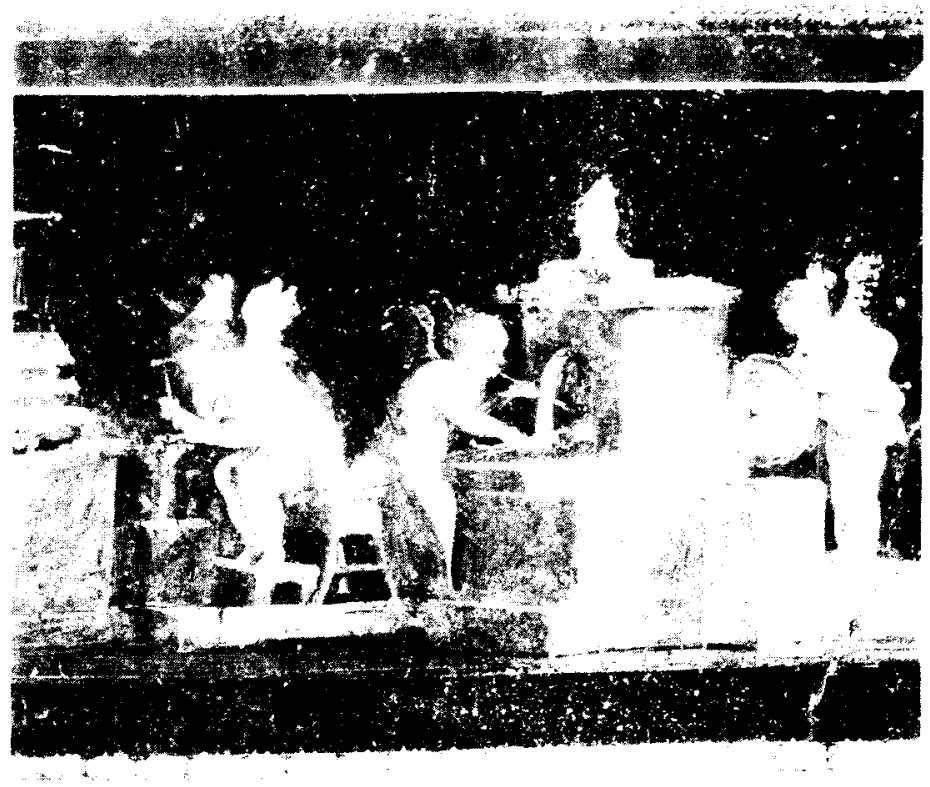

Fig. 2. Amorcillos-joyeros en su taller. Pintura al fresco pompeyana de la Casa de los Vetii. Pompeya,del s la. C. El de la zquierda moldea una joya con el martillo. El amorcillo central calienta el oro al fuego y el de la derecha imita los trabajos de la fragua de Vulcano.

Para la época en la que comienza a desarrollarse el arte arcaico, hacia el s. VIII a. C., se ha querido invocar la autoridad de Homero ${ }^{11}$, que presenta a los orfebres como artesanos itinerantes, que transportaban sus productos, sus técnicas y su estilo, de una región a otra, incluso de país en país. En realidad, si las joyas tuvieron la movilidad que su valor y ligereza les permiten, los orfebres, a partir de la época histórica al menos, no viajaron más que otros obreros.

Nada parece distinguir particularmente a los cinceladores de oro de los otros artesanos, sino su maravillosa habilidad. Sus talleres estuvieron más - menos ricamente dotados, y, sin duda, los métodos, los procedimientos, incluso ciertos productos, varían poco de un siglo a otro, o de una ciudad a otra.

Odisea, Ill, 425 y ss: “... Mande venir al orifice Laerces para que vierta oro en los cuernos de la novilla... Presentóse el orifice trayendo en la mano las broncineas herramientas - yunque. martillo y tenazas - mediante las que trabajaba el oro: compareció Minerva... y Néstor dio el oro y el artifice, después de prepararlo. lo vertió alrededor de los cuernos de la novilla para que la diosa se holgara al ver el adorno." 
Desde la época arcaica, entre los griegos como entre los etruscos, lo esencial de la técnica se había adquirido ya. La enseña del orfebre Brattiarus, conservada en el Museo Vaticano (fig. 3), sería igualmente sugestiva a los ojos de un público ateniense del siglo de Pericles, como lo fue, sin duda, para el pueblo romano de la época imperial. La enseña de Brattiarus (nombre de oficio muy próximo al apelativo profesional bractearius) o de su precursor griego o etrusco, es una muestra de las actividades primeras de estos artesanos. En ella, se reproduce a un joyero martillando un lingote de oro sobre un yunque, para transformarlo en una hoja. A la derecha, aparecen una pila de lingotes y una balanza que servía para precisar la cantidad de metal abastecido.

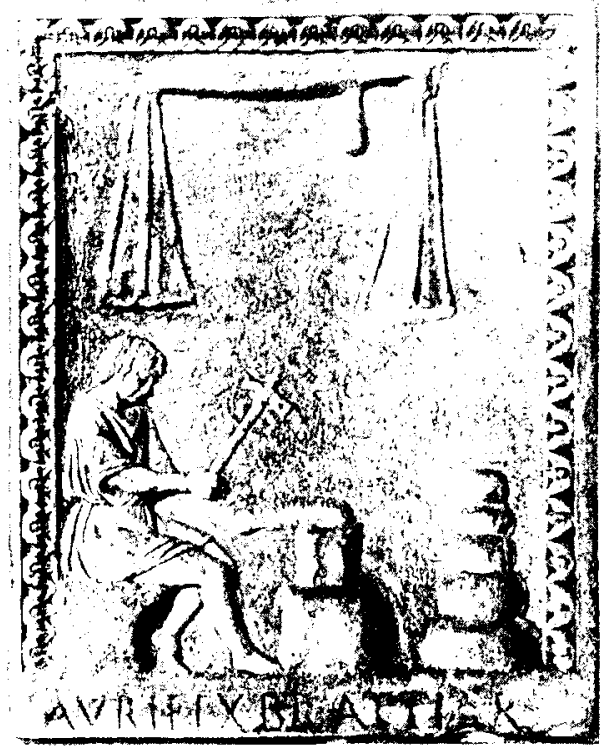

Fig. 3. Enseña de joyero romano. De mármol. Siglo I d. C. Roma. Museo Vaticano

\section{LA EDAD MEDIA 12}

Durante la Edad Media, en Europa Occidental, los orfebres trabajaron metales preciosos, como el oro y la plata, enriqueciéndolos con piedras raras y gemas grabadas. Sus principales trabajos consistían en anillos,

\footnotetext{
Desarrollamos esta época más extensamente que otras, porque en ella se constituyen los elementos definitorios del joyero, técnicas y organización.
} 
broches, vasos y otro tipo de recipientes, así como adornos preciosos. A veces trabajaban con aleaciones de cobre, que decoraban con esmaltes y dorados, y aún no se había establecido la diferencia de concepto entre orfebre y platero.

Existían dos tipos de artesanos: los monásticos y los seglares, que, según su rango y valia, podían ser pobres aprendices o riquísimos artesanos. La riqueza de un orfebre se estimaba en función de la naturaleza de los metales con los que trabajase.

En la Edad Media, metales como el oro y la plata, que aparecían nombrados en la Biblia ${ }^{13}$, eran considerados como preciosos y, por lo tanto, dignos de reyes y nobles. Un claro ejemplo de ello nos lo muestra el poeta alemán. Wolfram von Eschenbach ${ }^{14}$ (hacia 1200), quien relata un banquete en la corte del Rey Arturo, al que acudiera Parcival o Parsifal y en el que se usaron costosas copas de oro, adornadas con piedras preciosas. Nos narra igualmente, la copa de esmeralda o Santo Grial que sirvió a Jesús en su Ultima Cena.

El hecho de que la Biblia aludiera a ciertos materiales preciosos (fig. 4) para referirse a atributos divinos, le sirvió al abad Suger de Saint-Denis (París, abad desde 1122 hasta su muerte, en 1151) de argumento para justificar el uso de metales y piedras preciosos en adornos, prendas y re!icarios, bajo su administración ${ }^{15}$

Inna de las principales fuentes para conocer el trabajo, organización, etc., de los orfebres en aquella época, es un manual titulado, De Diversis Artibus, escrito por un monje del siglo xII, llamado Teófilo (fig. 5). Dicha obra es la primera en recoger, de un modo bastante realista y objetivo, una amplia gama de procesos técnicos. Escrita entre 1110 y 1140 , consta de tres tomos: el primero trata de pintura; el segundo del trabajo en vidrio; y el tercero del îrabajo en metales preciosos. Este último sólo pudo haber sido escrito por un orfebre, dada la amplitud de conocimientos sobre este arte. El prefacio al tercer libro, escrito en latín culto, refleja el papel que desempeña la belleza en la Casa del Señor, de tal modo que la riqueza y belieza en el arte son un modo de proclamar las grandezas de Dios. De ahí que los orfebres de la época hayan de realizar numerosos

Saimo 12. 6: Proverbios, 30. 5: Éxodo, 19 y 28

" Autor de Parsifal. que es la leyenda del Santo Grial. MAUER, F. "Woltram von Eschenbach". Diccionario Bompiani de autores literarios. T.V. Barcelona, 1987

En Liber de rebus in administratione sua gestis, op. cit., expone y defiende sus ideas y actuación. V. también Arte medieval II. Románico y gótico. IA. Textos teóricos, estéticos, simbólicos 4., págs. 31- 35 . 


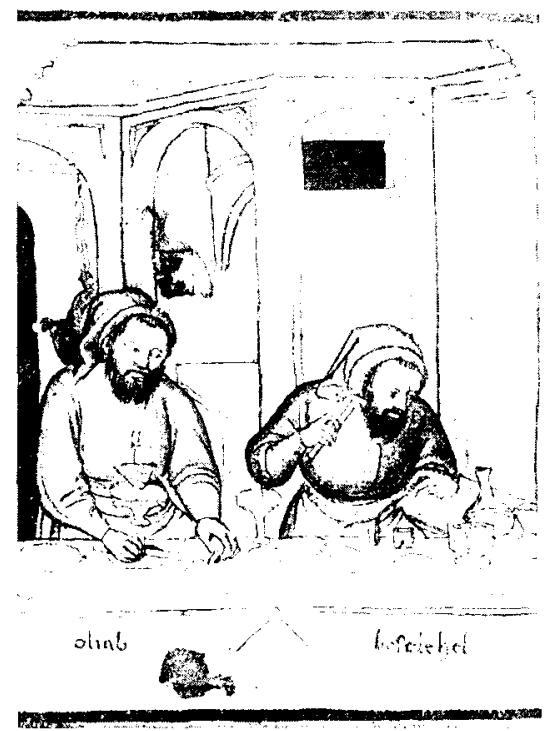

Fig. 4. Joyeros judios del Antiguo Testamento. Ms. de h.1400, probablemente de Padua. Representa la historia del libro de Exodo. de Bezael y Oliad. fabricando objetos liturgicos para el tabernáculo.

\section{7}

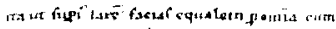

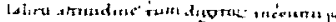

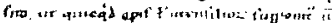

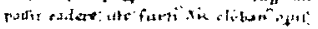

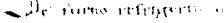

$t_{1}$

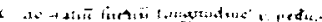

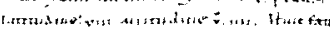

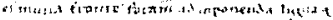
ran

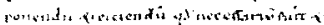

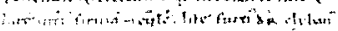

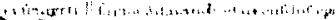
fo for

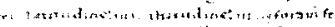

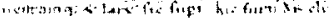

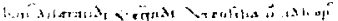

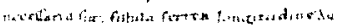

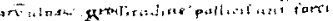

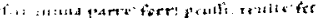

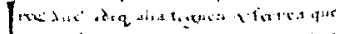

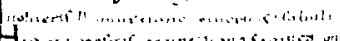

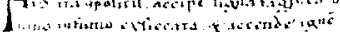

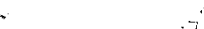

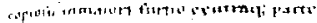

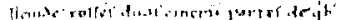

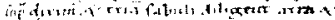

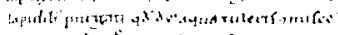

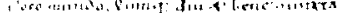

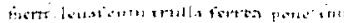

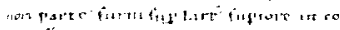

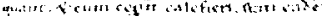

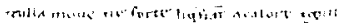

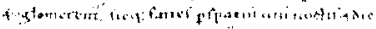

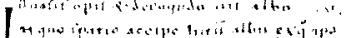

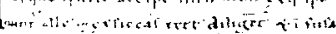

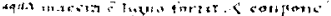

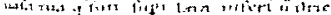

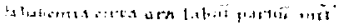

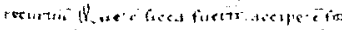

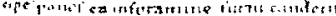

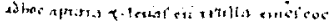

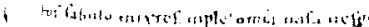

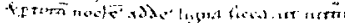

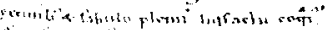

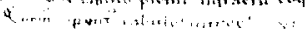

Fig. 5. Pasaje de Teofilo, De Diversis Artibus describiendo las herramientas del joyero y la construcción del horno. 
encargos de recipientes sagrados, como cálices, incensarios, candelabros, vinajeras, relicarios, cruces y cubiertas para las Sagradas Escrituras.

Para comprender este periodo, hay que tener presente el conflicto que enfrentaba a los monjes benedictinos cluniacienses -quienes, a través de Teófilo, defendían el uso de materiales preciosos-, con los cistercienses -quienes, a través de San Bernardo de Claraval, con una Apología ${ }^{16}$ escrita en 1122/3-, criticaban la lujosa ornamentación de las iglesias monásticas.

Otro testimonio importante de la época es el del inglés, maestro en París, Alexander de Neckham (1157-1217), quien en su obra De natura rerum ${ }^{17}$ describe el taller de un joyero del siglo XII, que comentamos en el apartado correspondiente.

En cuanto a la Baja Edad Media, no se conservan testimonios escritos, salvo ocasionales contratos para la fabricación de objetos especificos, y en ellos sólo se recoge el nombre del orfebre, así como el método de fabricación empleado. Ahora bien, las mejores fuentes escritas sobre las actividades de los orfebres de aquella época son las facturas de pago de productos, que se guardaban en los archivos de los patrones -reyes, duques, ricos nobles y obispos-. Una de las más fidedignas, de época algo posterior, son los inventarios que incluian, a veces, los testamentos de mercaderes y nobles, en los que se describían o recogían piezas como recipientes de oro y plata. Estos inventarios no solian nombrar a los orfebres y no se pueden relacionar con los objetos de la época que se han conservado.

Tal vez la principal fuente escrita sean los registros o actas de los gremios, que pretendian controlar las actividades de aquéllos que trabajaran el oro o/y la plata. Este testimonio es útil, en el sentido de que recoge lo que los orfebres debían o no hacer, pero no muestran lo que en realidad hacian.

Asimismo, son importantes las fuentes pictóricas, esculturas, grabados -eri madera, etc.-y ocasionalmente manuscritos. En estos testimonios pictóricos, aparecen representados orfebres - monásticos y laicos-y sus

San Bernardo, "Apología a Guillermo de Saint Thierry", cap. XII, págs. 824-854, en Obras completas, II. B.A.C., Madrid, 1955.

Alexander Neckham, Neckam. Necham o Necquam, teólogo, abogado y médico inglés Ingreso en la orden de los agustinos. Escribió De Laudibus Divinae Sapientiae, De Contemptu mundi. De utensilibus, algunos relacionados con la tarea del orfebre y cuyos manuscritos se hallan en la Royal L.ibrary en el Museo Británico. W.H., "Neckham», The dictionary of national biography, por George SMir. Londorı, 1917 
santos protectores (San Eligio o Eloy, patrono de plateros, joyeros y herreros en muchos países de Europa y de la América hispana, como San Dunstan lo es en Gran Bretaña ${ }^{18}$ ), trabajando o posando en sus tiendas o talleres (figs. 6, 7 y 8 ).
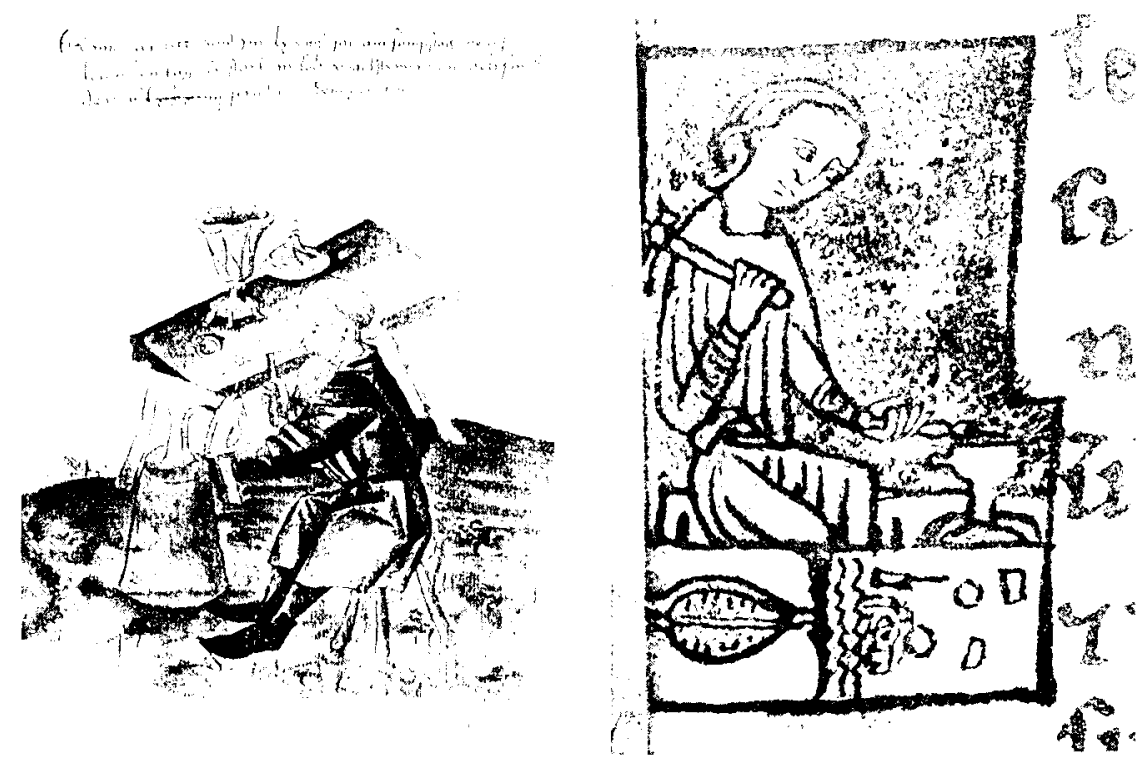

Fig. 6. Jovero en su trabajo utilizando el yunque y el martillo. Miniatura del MendelschenHausbuch, de Nuremberg, 1469. Otro ejemplo, de h. 1220-1230

Existe una fuente de tipo arqueológico, que nos puede ayudar a conocer la profesión del orfebre en la Edad Media. Por un lado, el estudio de las herramientas e instrumentos empleados en la fabricación de objetos - martillos, moldes y crisoles-. Por otro lado, el conocimiento de los propios talleres y su ubicación. Desgraciadamente, en la mayoría de los casos, estos edificios desaparecieron o se transformaron.

Acaso la fuente más importante sean los propios objetos de orfebrería que se han conservado hasta nuestros días. En su mayoría, no solían estar datados y se desconoce su lugar de origen. A diferencia de los orfe-

18 "Historia de san Eloy", Enciclopedia de la plata española y virreinal americana, por Alejandro Fernandez, Rafael Munoa y Jorge Rabasco, Madrid, 1984, págs. 1-3.- Sanz Serrano. $M$ a Jesús. Una Hermandad gremial. San Eloy de los plateros, 1341-1914. Sevilla, universidad, 1996. 

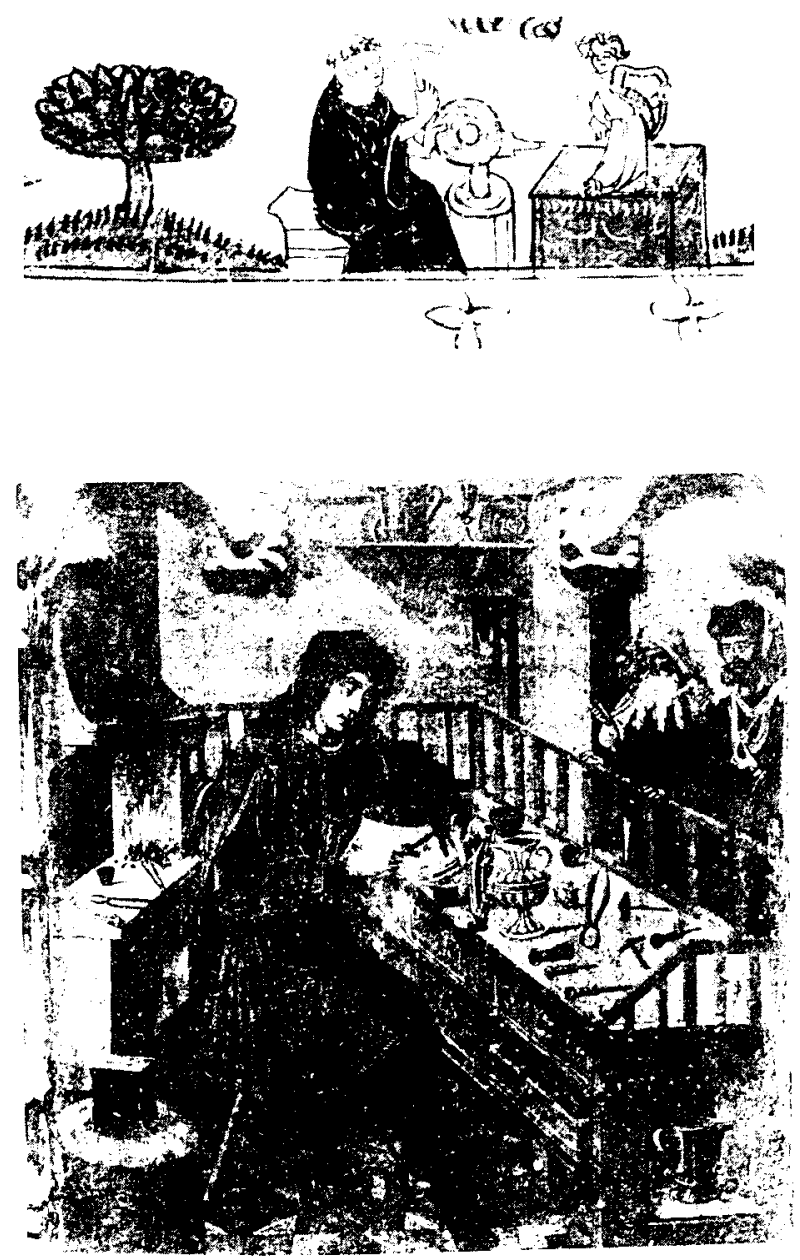

Fig. 7. En ocasiones, ei orfebre será San Dunstan, cuyo trabajo es amenizado por un ángel que toca el arpa. como en esta ilustración medieval, o San Eloy en su obrador, en el que pueden verse sus abundantes herramientas y perfecta organización de su trabajo. Pintura gótica catalana.

bres más modernos, que solían marcar sus piezas, con la fecha y lugar de realización de la pieza, este sistema no se utilizó en la Edad Media y comenzó a desarrollarse al finalizar esta época. En casos excepcionales, las piezas medievales llevaban el nombre de los artesanos, pero esto era muy poco frecuente.

Por último, los registros legales y los de las organizaciones artesanales, que recogian los nombres de los orfebres, sus herederos, lugares de tra- 


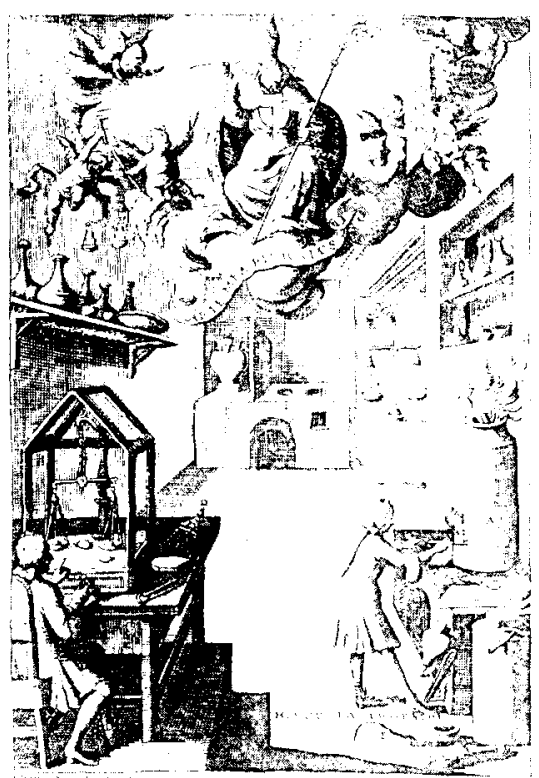

Fig. 8. A veces, la iconografia de San Eloy o San Dunstan lo presentará investido de obispo, como en el grabado de Matías Yrala, en el que, sobre nubes y con acompañamiento angélico, bendecirá el trabajo de sus cofrades.

bajo, posición oficial y rango en el gremio, son otra fuente importante de información de dicha época.

No obstante, apenas hay testimonios que describan los puntos más importantes, como son: el modo en que los orfebres desarrollaron sus habilidades, influencias que recibieron, libertad de que gozaron a la hora de diseñar sus piezas y relaciones artísticas con otros orfebres.

\section{a) Materiales}

Los principales materiales con los que trabajaban los orfebres eran el oro y la plata. El oro solía presentarse como metal nativo, bien como vetas en rocas de cuarzo, bien en sedimentos derivados de la erosión de dichas rocas. La forma más sencilla, aunque la más tediosa, de extraer el oro de las arenas y lechos de los ríos, consistía en usar una batea. Este proceso consistía en tomar en un plato o recipiente hondo arena con agua, removiéndose el recipiente, de modo que el cuarzo, más ligero, flotaba hacia el borde y el oro, más pesado, se quedaba en el centro. 
Teófilo ${ }^{19}$ describió este modo de extraer oro de las arenas de los bancos del río Rhin. Después de extraerlo, se colocaba el oro en un recipiente al que se añadía mercurio (o azogue) para entremezclarlos. Luego, se vertía la mezcla sobre una tela especial, se sacaba el mercurio y se colocaban los restos en un crisol, en el que se calentaban. Este método del uso de la batea se empleaba a veces en las minas, cuando las vetas de oro eran muy finas (fig. 9).

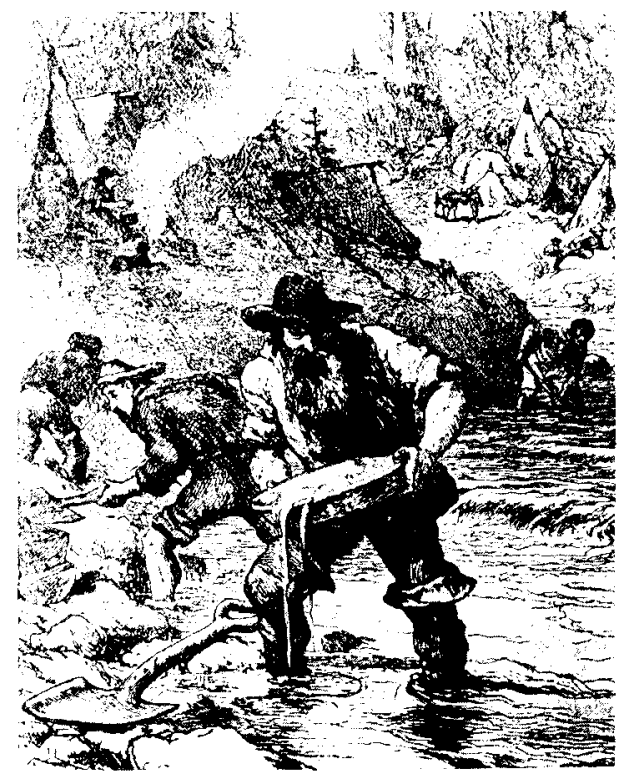

Fig. 9. Recogida del oro. Las pepitas de oro son raras, sin embargo el oro puede extraerse cuidadosamente de las vetas de la roca madre o pueden deshacerse en los aluviones, en diminutas partículas desgastadas por la erosión. En un cedazo se toma la arena del lecho del rio y se remueve hasta que las partículas de oro desciendan al fondo por su peso.

Durante la Alta Edad Media, las regiones de Europa Occidental y Central produjeron muy poco oro. Durante la antigüedad, se había acumulado gran cantidad de oro, que se reciclaba una y otra vez. En muchos casos, el oro que usaba un orfebre londinense o parisino, del siglo XIV, bien hubiera podido proceder de una moneda árabe o una cruz bizantina, o de cualquier joya romana e incluso egipcia. La caída del imperio romano no implicó que se dejara de emplear el oro en Occidente, ya que los reinos 
bárbaros siguieron acuñando y usando monedas de oro, asi como joyas en oro, hasta el año 700, aproximadamente. El oro que se empleó en este período solía proceder más bien de piezas antiguas, en lugar de extraerse. La decadencia que sufrió el uso del oro en Occidente, después del año 700 , se debió al hecho de que la fuerza del imperio oriental de Bizancio se atrajera todas las existencias de oro. Constantinopla exportaba productos de lujo, como telas — de algodón, seda, lino, etc.-, que se pagaban con oro. De hecho, los emperadores bizantinos acumularon grandes tesoros de oro. De ahi que la plata pasara a sustituir al oro en la acuñación de monedas, en Europa Occidental, a partir del 700.

No obstante, los árabes volvieron a extender la acuñación de monedas de oro, al extraerlo de zonas de Nigeria y de la Costa Dorada de África Occidental. Teófilo relata que este oro de origen árabe era de una tonalidad roja excepcional.

A partir del siglo xil y en adelante, los Cruzados llevaron muchas monedas de plata a los reinados latinos de la zona oriental del Mediterráneo. Estos reinos, sin embargo, preferian la acuñación en oro. de ahí que se atrajeran el oro de los paises árabes vecinos.

En el siglo xIII, ciudades italianas, como Génova, Florencia y Nápoles, exportaban plata y recibían a cambio oro en forma de monedas árabes. Éste debió ser el principal motivo por el que se volvió a introducir la acuñación de monedas en oro en Europa durante dicho periodo. En algunos casos, este oro pudo proceder, asimismo, de nuevas fuentes o minas descubiertas en Europa. De cualquier modo, los principales distribuidores de oro, en la zona mediterránea especialmente, fueron los árabes. Dicho oro se distribuyó a través del comercio.

Durante los siglos XIV y XV, se incrementó la demanda de oro, demanda que se satisfizo con el oro de origen árabe, pero también extrayéndolo de minas europeas.

Las minas europeas, no obstante, no produjeron grandes cantidades de oro, desde el primer momento. El lavado de las zonas auriferas que había en el cinturón, que se extendía del Rhin a los Cárpatos, fue posible gracias al desarrollo de norias que extraían el agua sobrante y evitaban las inundaciones y desbordamientos. La primera mina que produjo oro en Europa fue la de Trenmitz, en Bohemia, descubierta en la década de 1320. Zonas importantes de extracción de oro fueron: Silesia, Bohemia, Thuringia y los Alpes orientales. En la Alta Edad Media, Hungría fue el principal productor de oro, mientras que, en Gran Bretaña, por ejemplo, no se tiene constancia de que se extrajera oro durante el amplio periodo que abarca desde la invasión romana hasta el sigio XVi. 
Durante la Edad Media, el oro circulaba en forma de monedas -bizantinas o árabes españolas-, en lugar de en forma de lingotes o barras.

La plata fue el segundo metal precioso. A diferencia del oro, Europa Occidental (Francia, Italia, Alemania, etc.) produjo constantemente plata. Las minas de plata europeas más ricas fueron descubiertas durante la segunda mitad del siglo XIII, en Kuttenberg, al este de Praga, de ahí que se produjera un florecimiento de la cultura checa, a finales de la Edad Media. Se ha estimado que alrededor de un cuarto de la plata, que allí se producía, se acuñaba en monedas, mientras que el resto se exportaba en forma de barras. Este período de esplendor decayó en el siglo XV, al verse arruinádas las minas de Bohemia por las guerras de Husita.

La plata, como el oro, se podía fundir y volver a usar. Se tiene constancia de que, durante el siglo xill particularmente. se extrajera plata de minas inglesas, aunque el grado de pureza o refinamiento variaba según la región.

En cuanto a las gemas o piedras, que se engastaban en dichos metales, una de sus principales fuentes fueron los camafeos e intaglios del mundo clásico, que, durante la Edad Media, se engastaron en anillos, sellos y otras piezas de metal.

Los camafeos eran piedras preciosas con diferentes capas de color, de las que la superior se tallaba formando un diseño, mientras que la inferior formaba el fondo. Los intaglios eran piedras en las que se grababa un diseño en profundidad. De este modo, los camafeos e intaglios, rescatados de las antiguas ciudades romanas, fueron reutilizados durante el medievo.

Otras gemas, como rubies y zafiros, se extrajeron de regiones orientales, durante el período medieval. Los rubies procedian de la India y Ceilán; los zafiros de Ceilán, Arabia y Persia. Las esmeraldas procedian de Egipto, las turquesas de Persia o el Tíbet, y las amatistas de Alemania o Rusia. Durante la Alta Edad Media, fue raro el uso de diamantes, pero su uso se hizo más común durante los siglos xIV y x . Procedían de la India 0 de África Centra!.

Los mercaderes de piedras orientales se desplazaban por el Mediterráneo, siendo los judíos instalados en Italia, una de las comunidades principales en desempeñar un papel fundamental en este tipo de comercio. Un testimonio importante son los inventarios o listas de gemas, que hacían los judíos, en los que incluían sus precios, tamaño, valía...

Entre las reglamentaciones de las Compañias de Orfebres, una de las principales regulaciones pretendía impedir el tráfico o venta de piedras falsas. 
Algunas de las gemas y piedras preciosas procedían de Europa, y las principales fuentes de cristal de roca, usadas durante la Edad Media, se encontraban en Alemania, Suiza y Francia. Los ópalos y granates procedían de Europa Oriental. Las perlas se extraian de moluscos de agua dulce de ríos escoceses, y se perforaban para llevarlas montadas en un metal o cosidas a una prenda. El ámbar, resina de pino fosilizada, se extraía de las costas del Báltico y de la región de Königsberg, en el norte de Alemania. El azabache, restos fosilizados de árboles, se encontraba en zonas cercanas a yacimientos de carbón, en el norte de Inglaterra y en España. El coral procedía del Mediterráneo, sobre todo del Norte de África. El azabache, ámbar y coral se solían trabajar en Londres, especialmente para la fabricación de rosarios.

Tanto los orfebres como los plateros, trabajaban las gemas en cabujón, creando dicho efecto por el frotamiento y pulimentación de la piedra. La técnica de tallar en planos daba a las piedras un efecto más brillante y reflector (fig. 10).

En el siglo XIV, el diamante se solía tallar en forma de punta, por el sencillo método de partir por la mitad la forma octaédrica natural, en tanto que, a principios del siglo $\mathrm{xV}$, se empleaban modelos de talla de diamante muy sencillos, como la talla en sierra, en roseta o en rombo. Asimismo, en el siglo XIV, especialmente en París, se grababan los zafiros.

Aunque el Livre des Métiers, de Etienne Boileau (h. 1258-1269), enumerase listas de orfebres y joyeros a un tiempo ${ }^{20}$, el negocio del joyero 0 persona que preparaba la piedra se convirtió gradualmente en una artesanía más independiente.

\section{b) El orfebre medieval en su trabajo}

El taller era un ámbito indispensable para este artesano. Una de las mejores descripciones de él, de la época medieval, nos fue dada, como anunciamos, por Alexander Neckham (1157-1217), quien describió el trabajo de los orfebres parisinos a finales del siglo XII:

\footnotetext{
Étienne Boileau es autor de Réglements sur les arts et métiers de Paris rédigés au XIIle siècle et connu sous le nom Du Livre des métiers d'Etienne Boileau, publiés pour la prémière fois, en entier, après les manuscrits de la Bibliothèque du Roy et des Archives du Royaume avec des notes y une introduction, par G.-B. DEPPING. Paris, 1837. Da los "Registros de los oficios y su establecimiento en París", y, en el c. III, trata "Des orfèvres et de l'ordenance de leur métier", págs. 38-40. (BNM, s/27-29/69)
} 


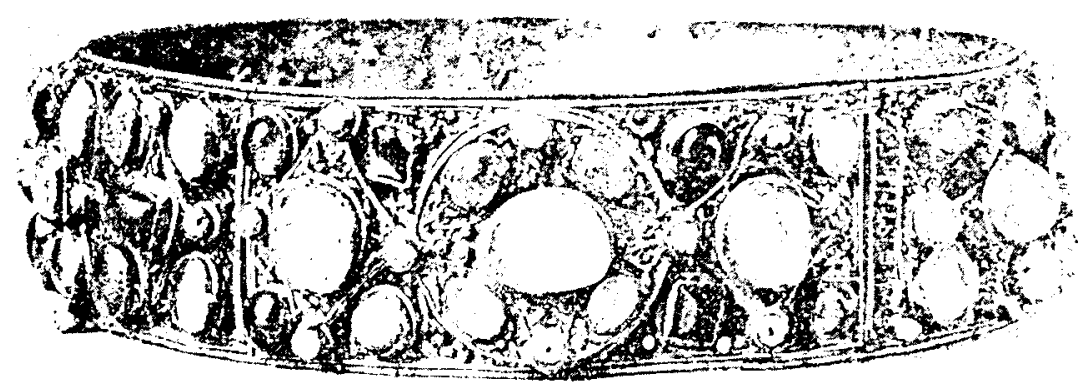

Fig. 10. Corona de la reina Cunegunda. Oro y piedras preciosas en cabujón. Munich, Résidenze.

“El orfebre debe tener un horno con un agujero en la parte superior, de modo que pueda expuisar el humo. Con una mano debe manejar el fuelle, haciendo una leve presión y con el máximo cuidado para que el aire que salga de la boquilla avive el fuego al ser descargado sobre el carbón. Debe tener un yunque de extremada dureza sobre el que se pueda extender el hierro o el oro y ablandarlos hasta darles la forma requerida. Se pueden estrechar y alargar con las tenazas y el martillo. Debe contar, asimismo, con un martillo para obtener hojas de oro, así como láminas de plata, estaño, latón, hierro o cobre. El orfebre debe tener un cincel muy afilado, con el que pueda grabar figuras de muchos tipos sobre ámbar, piedra dura, mármol, esmeralda, zafiro o perla. Debe poseer una piedra de toque para analizar y otra para distinguir el acero del hierro. Asimismo, debe tener una pata de conejo para alisar, pulir y limpiar la superficie del oro y la plata. Se recogerán las pequeñas partículas de metal en un mandil de cuero. Tendrá pequeños recipientes de cerámica y angarillas, una sierra dentada y una lima para el oro, así como hilos de oro y plata con los que reparar o reconstruir apropiadamente objetos rotos. Además, será tan habilidoso grabando como realizando bajorrelieves, o fundiendo, o martillando. Su aprendiz dispondrá de una mesa encerada, o bien cubierta con arcilla. sobre la que pueda retratar florecillas y dibujar de modos diversos. Debe saber cómo distinguir el oro puro del latón y el cobre, para que no compre latón por oro puro, ya que resulta difícil escapar a la astucia del mercader fraudulento" ${ }^{21}$.

Cabría destacar la pintura (fig. 11) de Niclaus Manuel (1484-1530), fechada en 1515 y encargada por el gremio de pintores y orfebres de Berna (Suiza), que narra la historia de San Eligio y representa a un orfebre trabajando un anillo con un cincel. Frente a él, San Eligio martillea un cáliz de plata sobre un yunque, y otro personaje trabaja la parte inferior de una

En Chtriky, John. Goldsmiths. Medieval Craftsmen, Londres, British Museum Press. 1992 pág. 24 


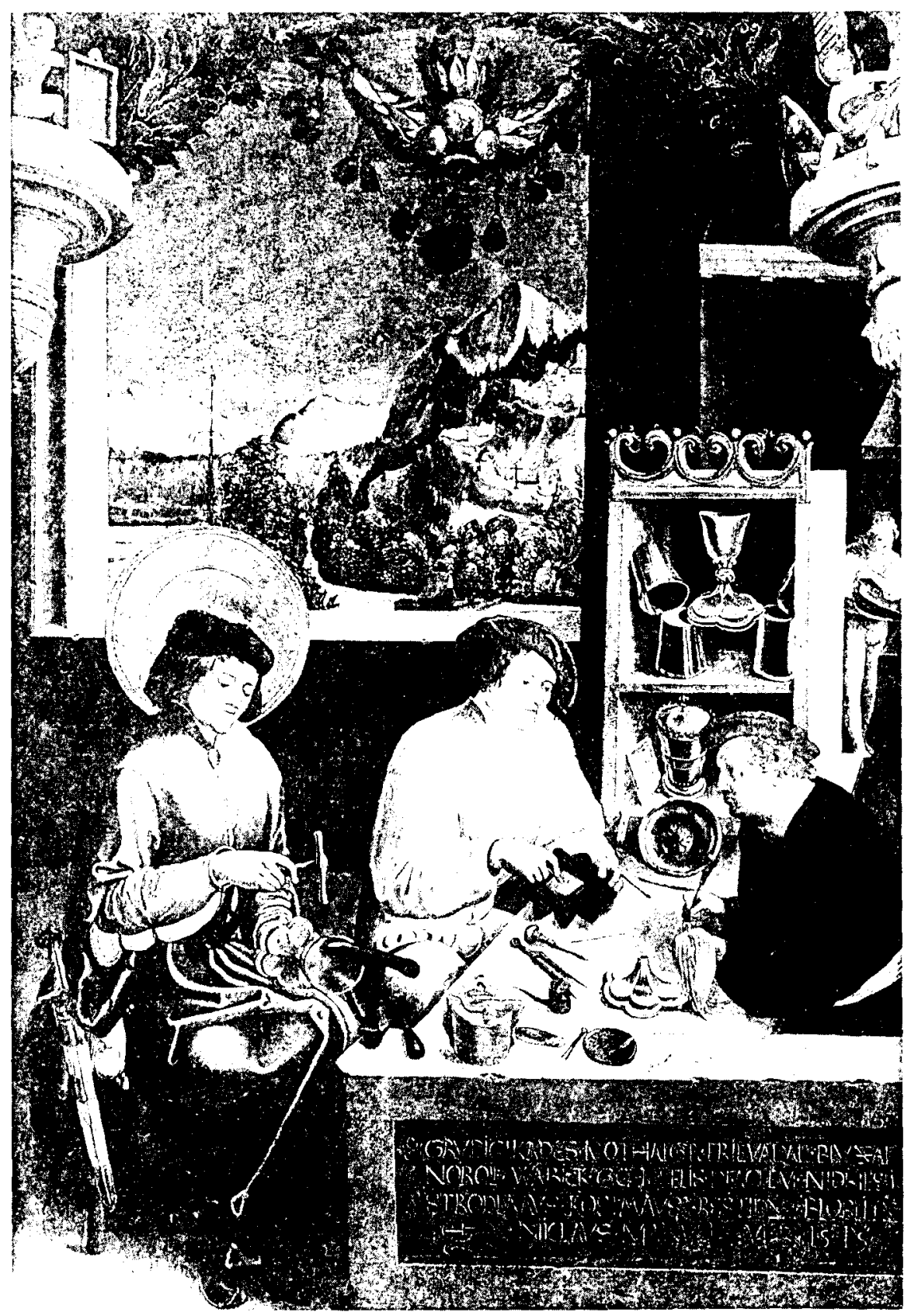

Fig. 11. Taller de San Eloy. Pintura encargada por el gremio de Berna, suiza, a Niclaus Manuel, en 1515 . 
copa. Esta pintura es interesante porque aparecen varias herramientas, como cinceles y compases o un plato llano... Al fondo, se ve al aprendiz avivando el fuego con un fuelle. Pese a que este cuadro sea bastante posterior a la descripción de Neckham, se puede concluir que, en esos trescientos años de diferencia, las herramientas que se usaban y el modo de trabajar apenas habían sufrido variaciones.

Ahora bien, tal vez, el mejor testimonio del trabajo del orfebre nos lo haya dejado el monje Teófilo. En su obra, describe el ideal de un monasterio, lo cual se ve por el modo en que describe el atuendo del metalista, demasiado ideal y raramente usado en la vida real. Explica que el taller debe ser espacioso y elegante, con muchas ventanas y dividido en tres secciones: una para el oro, otra para la plata, y una tercera para el proceso de fundición y de trabajo de los metales de base ${ }^{22}$ (fig. 12). Frente a las ventanas, habrá una mesa de trabajo con una zona hundida bordeada de madera, de modo que se puedan recuperar con cuidado las partículas de oro y plata. Cada banco debe tener situado a su lado un horno de trabajo, con fuelles hechos de piel de carnero. Por otro lado, hace referencia a las herramientas de un modo más explícito que Alexander Neckham. Por ejemplo, describe varios tipos diferentes de yunques: unos anchos, lisos y cuadrados, o lisos y con cuernos; otros, redondeados por arriba con forma de media manzana; o bien largos y estrechos... Asimismo, hace una descripción extensísima de los diversos tipos de martillos, tenazas, limas, cinceles, escofinas y herramientas para engastar, aunque quizá sean más gráficos los dibujos de la época. Resulta interesante una pieza que menciona, llamada organarium, que consistía en dos partes de hierro aseguradas con broches. Cada una de las dos caras internas iba grabada con estrías o surcos y tenían cavidades en el centro. Cuando se insertaba una pieza de oro o plata entre las dos caras de hierro, se golpeaba la parte superior con un martillo, y así se obtenía una cuenta de oro o plata. Uno de los capítulos más extensos del De Diversis Artibus daba instrucciones acerca de la fabricación, construcción y embellecimiento de un cáliz con nielo y dorado (fig. 12).

Hallazgos arqueológicos harı permitido localizar la ubicación de algunos de estos talleres. A través de estos hallazgos se ha comprobado que a menudo se tenía que purificar los metales preciosos antes de usarlos y reusarlos. Para separar el metal precioso del metal de base se empleaba la copelación, mientras que la plata se separaba del oro por un proceso

Los grabados de Etienne Delaune (Ausburgo, 1576) responden a esta descripción. 

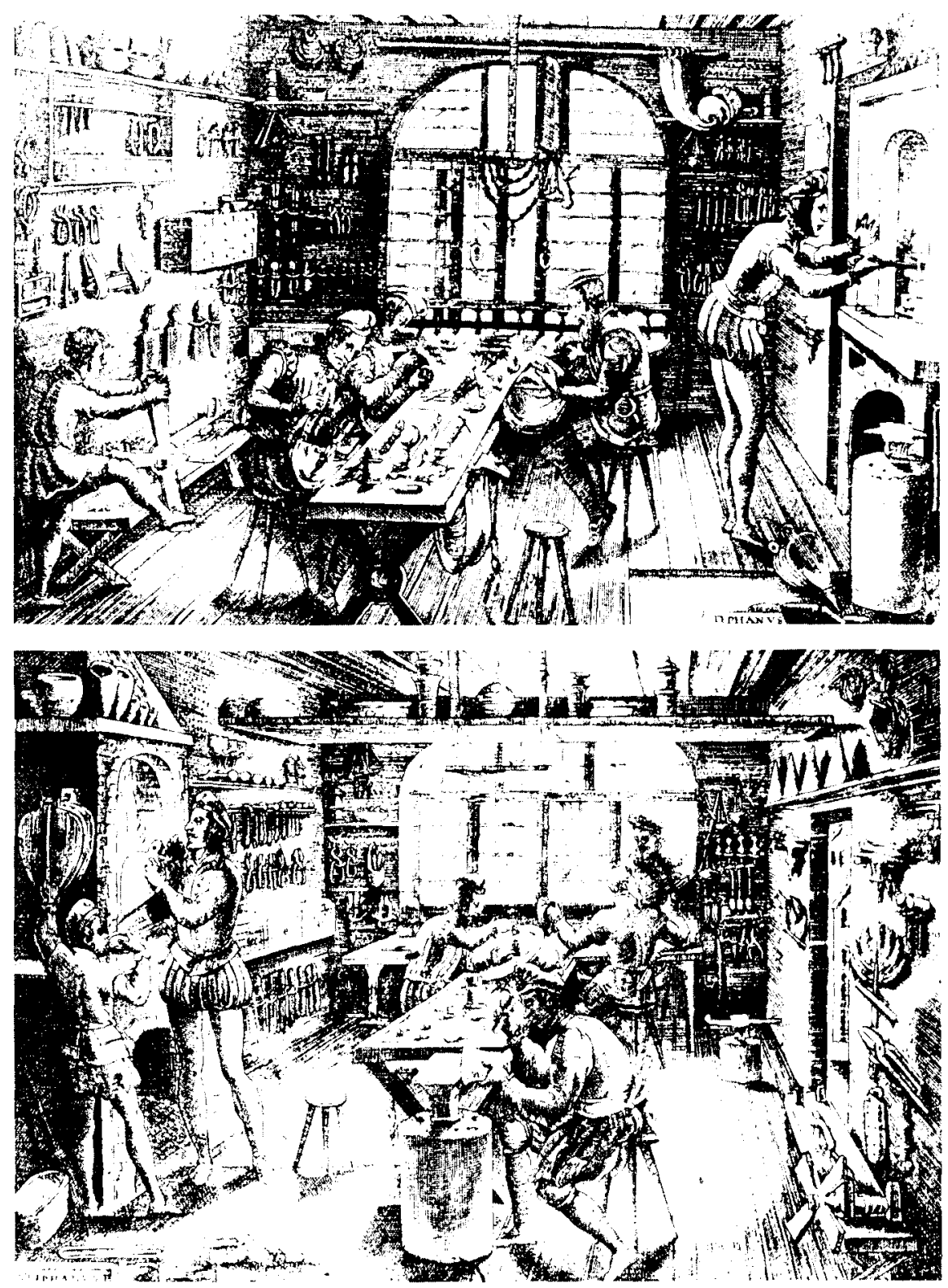

Fig. 12. Dos grabados de Étienne Delaune, Augsburg, 1576, son la expresión grafica de todos los pormenores. Biblioteca Nacional de Paris (Ed. 4 a Rés). 
conocido como desplatación. Primeramente, se mezclaba el metal con una gran cantidad de plomo, que se oxidaba para que produjera litargirio (u óxido de plomo), que disolvía cualquier tipo de metal base presente, quedando tan sólo el oro y la plata. Estos procesos se realizaban por lo general en recipientes de cerámicas o de otro tipo, que fueron los hallados por los arqueólogos en zonas urbanas del final de la época sajona y del medievo (en Inglaterra, París, etc.). Asimismo, se han hallado hornos con restos de metales, algunas herramientas, restos de vidrios e imitaciones de piedras preciosas.

Semejante es la descripción que, Fernández, Munoa y Rabasco ${ }^{23}$ nos hiacen del taller de un orfebre español, así como de las agrupaciones de las tiendas, obradores o boticas en calles dedicadas a esta especialidad. No lejos se ubicaba el Colegio o Cofradía, o la misma iglesia con la capilla de su patrón san Eloy.

De todos los trabajos artesanales medievales, el de los orfebres implicaba una serie de operaciones manuales e instrumentales, que requerían mayor cuidado que otro tipo de trabajos. Se exigian una gran paciencia y precisión para realizar los diseños, preparar los materiales y herramientas y ejecutar el trabajo. Por otro lado, era necesario conocer muy bien los materiales con los que se iba a trabajar, para conseguir el efecto deseado. Para trabajar el oro y la plata, se empleaban técnicas, como la elevación, la profundización y el repujado, pero las fundamentales eran la forja con martillo y la fundición. Las naturalezas diferentes de ambos metales conllevaban distintos métodos de trabajo. El oro puro es excepcionalmente maleable y se puede batir hasta obtener una hoja muy fina. La plata es menos maleable que el oro y tras martillearla prolongadamente necesita un recocido (recalentar suavemente y dejar enfriar). A veces las proporciones de oro y plata en los metales aleados variaban en función del efecto que se quisiera crear. En términos generales, la mayoría de los recipientes y platos o bandejas se forjaban, mientras que la joyeria y objetos decorativos se fundían. De cualquier modo, era muy corriente el uso del martillo $y$, de hecho, en algunas piezas se pueden ver huellas del proceso de martillado.

En ocasiones, el oro y la plata derretidos se fundian directamente en objetos o partes de objetos. En ese caso, el orfebre debía poseer las cualidades para modelar de un escultor. El proceso de fundición empleado se llama proceso a la cera perdida. Por ejemplo, Teófilo describe la fabri- 
cación de asas para un cáliz, haciéndolas previamente en cera y esculpiendo en ellas decoración en forma de dragones, animales o pájaros y dejándose un pequeño dedo de cera, llamado bebedero, en la parte superior. Luego, se cubria la cera con arcilla moldeada, de modo que todos los huecos del molde quedasen rellenos. Se calentaba el molde hasta que se derramaba la cera por los agujeros creados por los bebederos. Entonces, se vertía la plata fundida en los moldes a través de los mismos agujeros. Se enfriaba todo, se rompian los moldes y extraían las asas.

Cuando se querian realizar varios objetos basados en el mismo mode10, se empleaban moldes de metal o piedra fina granulada. Los arqueólogos no han podido determinar qué metales se fundian en los moldes hallados. Las matrices de metales eran, en algunos casos, de una aleación de cobre. De ese modo, se podían reproducir motivos en cantidades considerables, colocando una hoja del metal sobre la matriz y, sobre ella, una pieza de plomo que se golpeaba con un martillo.

Las joyas y objetos de plata se remachaban o soldaban. Se usaban dos tipos de soldadura: una soldadura de estaño de plomo con un punto de fundición inferior a los $250^{\circ} \mathrm{C}$; o una soldadura fuerte de cobre aleado con plata, o bien oro, con un punto de fundición superior a los $700^{\circ} \mathrm{C}$.

El oro y la plata se solían decorar con técnicas, como el repujado (que se obtiene trabajando el metal por el reverso), el engaste o cinceladura (elevando el metal por la parte frontal), o el grabado (en el que se ahueca con la gubia el metal).

Para crear efectos de colorido y contraste en la superficie de sus piezas, empleaban el nielo, piedras o esmaltes. El nielo era sulfuro de cobre o plata calentado en una superficie de metal grabada, de modo que quedara una superficie negra y mate, que contrastase con la plata y el oro brillante de alrededor. En la Edad Media, se fomentó la decoración con esmalte, ya que creaba un contraste de colorido con el metal precioso. El esmalte solía ser vidrio que, al ser calentado hasta su punto de fundición, se unía al metal con el que estaba en contacto. Sólo era estable si el vidrio y el metal empleados eran compatibles. La diferencia entre las distintas técnicas de esmaltado reside principalmente en el modo en que se preparaban las diversas superficies de metal para contener el esmalte. Existen multitud de técnicas para aplicar el esmalte al metal. El esmalte está contenido en bandas o franjas de metal, en cuyo caso puede ser cloisonné, afiligranado, champlevé o basse-taille. En el esmalte champlevé, se excavaba el diseño mordiendo la superficie del metal y se rellenaban los huecos con esmalte, a menudo con distintos colores en un compartimento. Esta técnica se solía emplear sobre una aleación de cobre, ya que reque- 
ría un metal de espesor considerable. La basse-taille, o esmalte translúcido, fue una técnica que se desarrolló a finales del siglo xix: se grababa un diseño en bajorrelieve sobre el fondo de la placa de oro o plata. Se podían obtener distintas tonalidades y modelos cambiando la profundidad del grabado, así como el espesor del esmalte. En segundo lugar, esta técnica podía aprovechar la propiedad del esmalte para fundirse al metal. Esto incluye la técnica del ronde bosse y del esmalte pintado. La primera era una técnica para esmaltar la superficie de figuras $u$ objetos en relieve 0 a veces en alto relieve. En esta técnica, desarrollada en el siglo XIV, se retenía el esmalte poniendo áspera la superficie de oro o plata.

La mayoría de las técnicas de esmaltado reciben nombres franceses, puesto que París fue uno de los principales centros de esmaltado del norte de Europa. En algunos casos, los orfebres realizaban sus propios esmaltados, pero en los grandes centros, como París, existían esmaltadores especializados.

En ciertos casos, las piezas decoradas con esmalte, y realizadas en oro $u$ otros materiales como la madera, el marfil o un metal, se decoraban con una hoja de oro. La realización de hojas de oro era un proceso lento. El orfebre martillaba el oro, a menudo en forma de moneda, en hojas finas y lo golpeaba con una variedad de martillos entre hojas de pergamino, hasta conseguir la ligereza deseada. El método habitual para dorar una aleación de plata y cobre consistía en dorarla con mercurio o al fuego. Después, se limpiaba el objeto y se aplicaba a las partes que debían dorarse, una amalgama de oro y mercurio, obtenida haciendo gotear una hoja o restos de oro sobre mercurio hirviendo, que luego se dejaba enfriar. Entonces, se calentaba el objeto, provocando que el mercurio se evaporase y dejase tras de sí una capa de oro lista para el pulido. El plateado se efectuaba de modo similar. El efecto final, conseguido en muchas de las obras de los orfebres medievales, fue el contraste entre el color de las piedras o esmaltes con las superficies brillantes de la plata y el oro.

\section{c) Orfebres monásticos}

Tras las invasiones vikingas de los siglos VIII y Ix, durante el período de recuperación económica, los monasterios se convirtieron en uno de los principales puntos de transmisión cultural. La Abadía benedictina de San Gall, en Suiza, posee un plano del siglo Ix del monasterio ideal. Dicho plano reproduce los diferentes talleres del monasterio, entre ellos los de los orfebres, que se situaban al sur de la iglesia de la Abadía, fuera del claustro, entre el granero, a un lado, y el horno de pan y el molino, al otro. 
Los orfebres trabajaban en un edificio anexo al taller principal, junto a la herrería, tal vez porque ambas actividades implicaban un peligro por el uso de fuego. A sus viviendas se accedía a través de los talleres (fig. 13).

Los monasterios fueron uno de los principales lugares de mecenazgo para los orfebres, dada la gran demanda de objetos en oro y plata, por parte de la Iglesia, para la celebración de los servicios religiosos. Hasta el

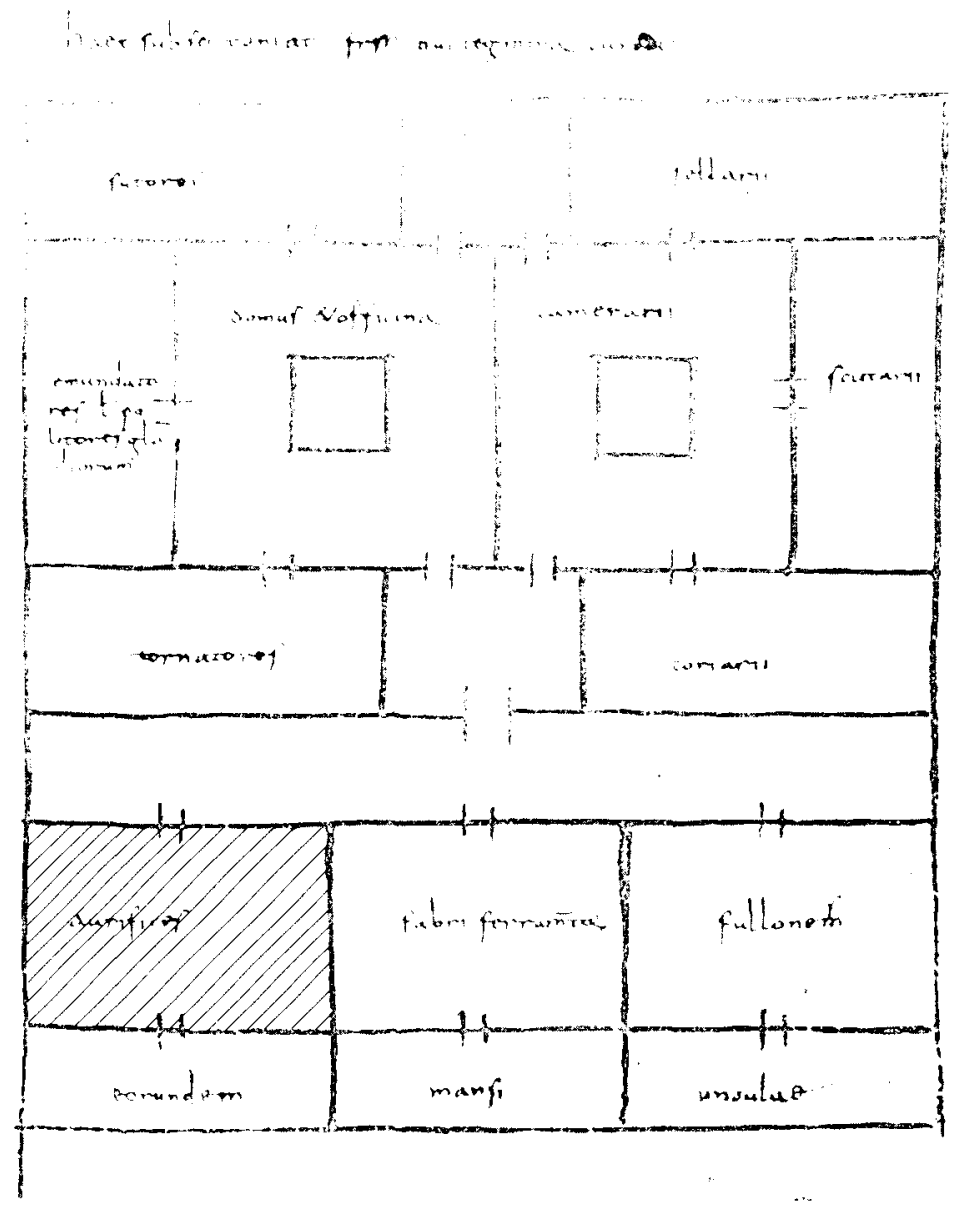

Fig. 13: A, Plano del monasterio ideal, del s. ix, conservado en la Abadia benedictina de San Gall, en Suiza. Entre todos los talleres, el del joyero-orfebre - aurifex- lo hemos distinguido con un rayado, junto al taller principal y a la herreria. 


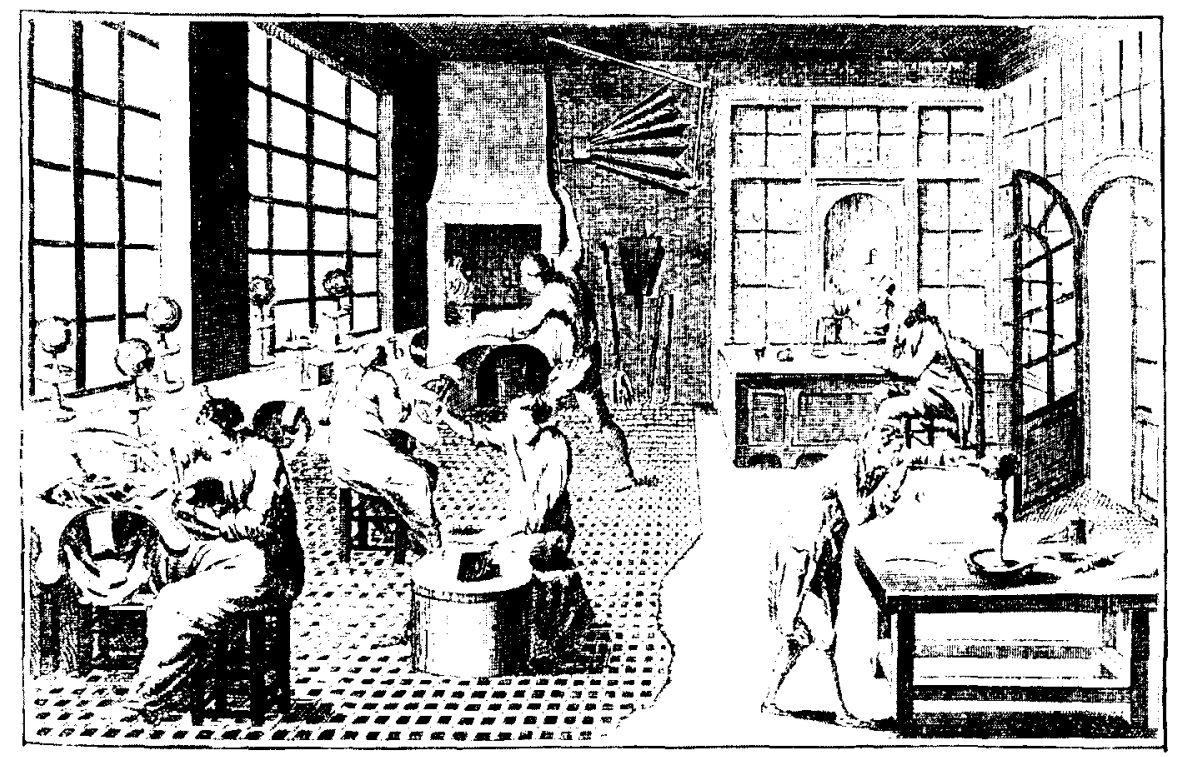

Fig. 13.B. Taller del joyero. Interior. Grabado de la Enciclopedia Francesa.

siglo xIII, la mayoría de los orfebres eran monjes, como, por ejemplo, fue el caso de Teófilo ${ }^{24}$. A cambio de este trabajo, la Abadia recibía una iglesia local y otros diezmos. De cualquier modo, sería erróneo imaginar que los grandes monasterios europeos de esta época tuvieran grandes escuelas de orfebres o que ciertas escuelas de orfebrería trabajaran para ellos.

Se solían contratar ios servicios de orfebres, cuando se les necesitaba, y a ser posible, se preferia la admisión de un orfebre, bien formado, en la hermandad, ya que resultaba mucho más económico que la contratación de un empleado externo o ajeno al monasterio.

Al parecer, durante los siglos XIV y $x V$, se produjo un declive en la producción artística de los monasterios, y dentro de ésta, de los trabajos de orfebrería. Esta decadencia no se debió tanto a la imposibilidad de los monjes orfebres por transmitir sus conocimientos y habilidades a sus aprendices, sino al hecho de que los orfebres dejaran de ser monjes. Los orfebres de la Baja Edad Media fueron ya hombres laicos, en lugar de monjes.

Según algunos eruditos. Theophilus podría haber sido la misma persona que el orfebre y monje, Roger de Helmarshausen, quien realizara un altar portatil para Henry de Werl, obispo de Paderborn, en el año 1100. 


\section{d) Orfebres seglares}

Los orfebres seglares solían trabajar más bien para emperadores, reyes y nobles en sus cortes reales y aristocráticas. Por otro lado, había orfebres urbanos que trabajaban por su cuenta. El florecimiento y crecimiento de las ciudades, debido al comercio, durante los siglos XI y XII, hicieron que aumentara el número de orfebres urbanos. El siglo XII fue testigo de un incremento del número de orfebres que trabajaban en ciudades, como Londres, París u otras capitales europeas.

Jean de Garlande ${ }^{25}$, en su Diccionario, escrito hacia 1220 , describe del siguiente modo a los orfebres parisinos:

"Los orfebres se sientan ante sus hornos y mesas en el Grand-Pont y realizan broches de oro y plata, alfileres y botones, y eligen granates y jaspe, zafiros y esmeraldas para los anillos. La habilidad de los orfebres extiende bajo el martillo láminas de oro y plata con martillos ligeros sobre yunques de hierro. Engasta gemas preciosas en las monturas de los anillos de uso entre nobles y barones. Los artesanos (...) cubren recipientes [de madera] con láminas de oro y plata y colocan pies bajo cuencos que coronan con círculos [bordes de metal precioso], de modo que sean más bellos, fuertes, duraderos y vendibles" ${ }^{26}$.

El hecho de que los orfebres instalaran sus tiendas o puestos sobre puentes, como ocurría también en Florencia (en el Ponte Vecchio), muestra lo importante que era para ellos tener sus tiendas en lugares donde pudieran atraer la atención de los mercaderes de paso por la ciudad. En Londres, los orfebres se reunian en torno a Cheapside, la calle principal que se dirigía hacia el este desde la Catedral de San Pablo (fig. 14). Los orfebres franceses se establecieron y dieron su nombre, en París, a la rue des orfèvres, en el barrio de Saint-Germain-l'Auxerrois, y al quai del Sena, que se extiende en una parte de la Isla de la Ciudad, entre el Puente Nuevo y el Puente de San Miguel.

A finales del siglo XIII y comienzos del XIV, se produjo un incremento del comercio y expansión urbana, haciéndose necesaria la regulación de los miembros y actividades de los gremios artesanales. El alcalde de París, Etienne Boileau, estableció una reglamentación, hacia 1268, conocida

\footnotetext{
Alquimista inglés, autor de un Compendium Alchymiae cum Diccionario ejusdem Artis, impreso en Basilea en 1560, y de un Liber de Mineralibus. impreso en la misma ciudad y año. Nouvelle Biographie Génerale depuis le temps les plus reculés jusqu'à nos jours. MM. Firmin Didot Frères, sous la direction de M. le D'HOEFEF. Paris, 1857. - Jacques-Charles Brunet, Manuel du libraire et de lamateur de livres. Paris, 1861.- George SMITH, Dictionary of National Biography. London, 1917.

2* En Cherry, John, op. cit, pág. 11.
} 


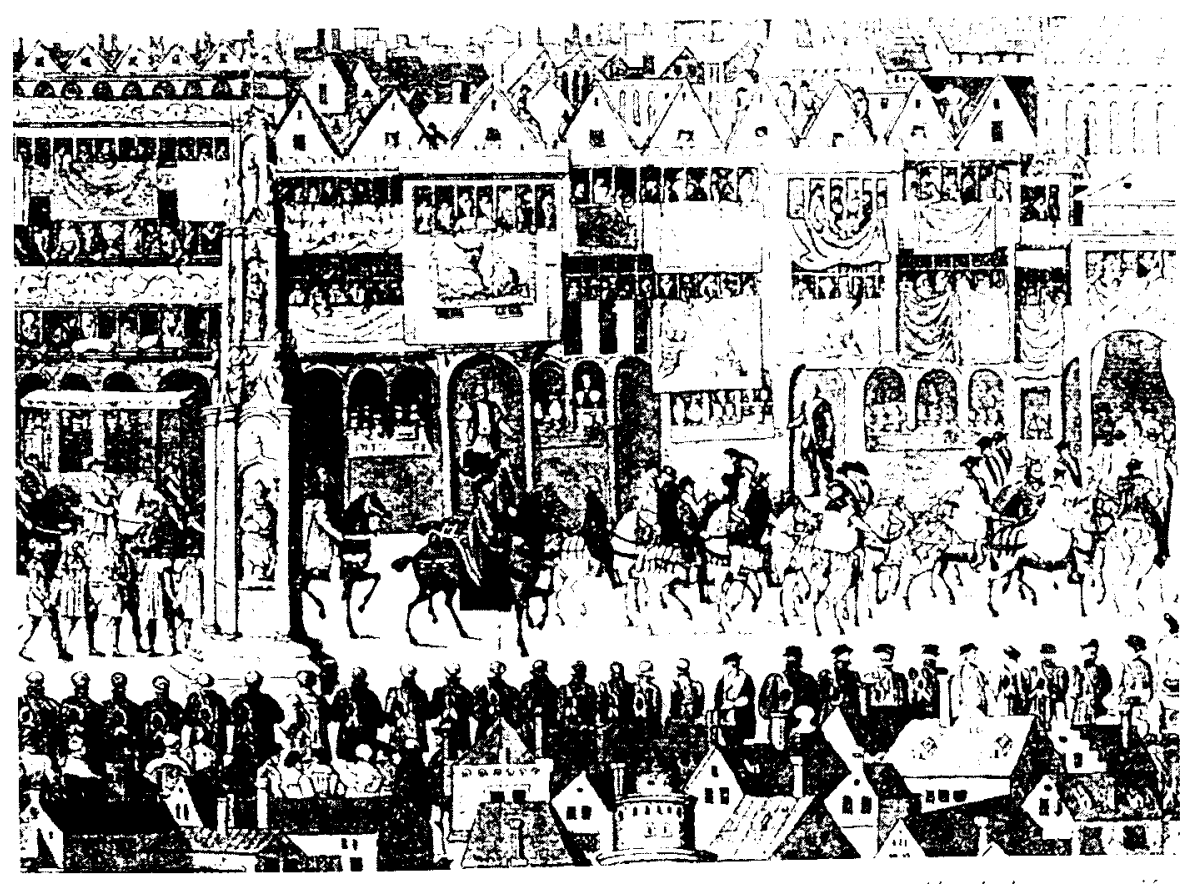

Fig. 14. Tiendas de joveros en Cheapside. Londres. Pintura de la procesión de la coronación de Eduardo VI, en 1547.

como el Livre des Métiers («Libro de las artesanías»). Este documento fue de vital importancia para el desarrollo de regulaciones similares en otras urbes europeas. En 1292, se realizó en París una lista de contribuciones, conocida como Livre de la Taille ("Libro de la talla») ${ }^{27}$, en la que se recogía el nombre de 116 orfebres y joyeros. En otras ciudades francesas, se observó una expansión similar de artesanos orfebres, hecho que se nos revela por la necesidad que surgió de marcar las piezas con distintivos que indicaran sus lugares de origen.

En 1275, el rey francés, Felipe el Atrevido (que reinó de 1270-85), ordenó que en aquellas ciudades en las que trabajaran plateros, lo hiciesen en plata refinada, y que cada ciudad tuviera un distintivo propio para marcar la plata. Así, ya en la primera mitad del siglo XIV, se conocen las marcas de una serie de ciudades francesas, como Grenoble, Toulouse, Tours, Rouen, Carcassonne, Arras y Albi. 
En Gran Bretaña, Londres adopta una marca en 1300, y se sabe que se produce una gran expansión del número de orfebres, durante la primera mitad de ese siglo, porque la Compañía londinense de Orfebres ("London Company of Goldsmiths") adquiere en 1327 una Carta Real. Hacia 1368, la Compañía contaba con unos 135 orfebres.

El número de orfebres que trabajaban en Europa se incrementó hasta que la peste negra devastara el continente en 1348. Sin embargo, aumentó gradualmente a lo largo del siglo xv. El trabajo de orfebrería floreció en las principales ciudades europeas de aquel momento: Brujas, Utrecht, Lübeck, Florencia y Estrasburgo. En Alemania, los orfebres se concentraron en la zona de Colonia, donde, desde 1395 hasta principios del XVI, hubo una media de 122 maestros trabajando en aquel área.

Para los orfebres londinenses, fue de suma importancia el mecenazgo real, ya que los soberanos, no sólo intentaban controlar el suministro y calidad de metales preciosos y su acuñación, sino que además, encargaban láminas de oro y plata, para los sellos reales, relicarios y cruces, entregados a iglesias y monasterios.

Ahora bien, no todos los orfebres poseyeron negocios ricos y prósperos y alcanzaron un alto rango en la vida política de su ciudad. Por ejemplo, según unos estudios realizados en Utrecht, sólo un $10 \%$, de los supuestos 280 orfebres que alli trabajaban, lograron abrirse camino en la vida politica de esta ciudad.

Se han conservado muy pocos retratos de orfebres del siglo xv. El más destacado es el trabajo primerizo de Jan van Eyck, pintado en 1436, en el que retrata al deán del gremio de orfebres de Brujas, John de Leeuw. Éste sostiene un anillo engastado con una piedra, bien para mostrar que estaba comprometido o como símbolo de su trabajo artesanal. Existe otro retrato posterior, realizado por el pintor de Brujas, Gerard David (h. 1500), en el que representa a un orfebre que parece dirigirse a una persona externa a la pintura, a la que ofrece un anillo que acaba de extraer de un rollo de pergamino, que sostiene en la mano izquierda. Los trajes elegantes, con que visten ambos hombres, nos indican la prosperidad de los orfebres flamencos de la Edad Media tardia.

\section{e) Organización del gremio}

La actividades de los orfebres medievales como artesanos eran controladas por los gremios. Éstos eran asociaciones de personas que compartían una determinada devoción religiosa (por ejemplo, un santo 
en particular), o bien, grupos de ciudadanos, destacados y, a veces, artesanos.

El gremio controlaba la actividad de los artesanos, la calidad de los metales preciosos con los que trabajaban, la vida social de los mismos y la influencia que los orfebres emigrados ejercían sobre los oriundos de un lugar. Regulaban también el comercio, la calidad del producto, formas de producirlo, competencia de los artesanos y aprendizaje de los nuevos miembros, así como la vida social de los mismos y se encargaban de organizar una serie de funciones ceremoniales, conmemoraciones, etc.

El santo patrón de los orfebres ingleses era, como dijimos, San Dunstan, mientras que el de la mayoría de los gremios del resto del continente europeo, fue San Eligio. San Dunstan fue un monje benedictino que efectuó numerosas reformas monásticas en Inglaterra durante el siglo $x$ y que llegó a ser arzobispo de Canterbury (960-88). Según la leyenda fue un diestro metalista y fundidor de campanas.

San Eligio o Eloy, fue obispo de Noyon y Tournai (641-60). Tenia gran talento patra grabar y para la platería, trabajos que desempeñó y desarrolló en las Casas de la Moneda de Limoges y Marsella.

Por toda Europa los orfebres se asocian en gremios. Por ejemplo, en Paris, como se indica en el artículo del "Orfebre», de la Enciclopedia Francesa, este cuerpo es muy antiguo; sus primeros estatutos son del año 1260 y, al parecer, se redactaron basándose en otros anteriores. También en Montpellier existia un gremio de orfebres desde finales del siglo xill. En Londes, en el siglo xil1, existía una Fraternidad de San Dunstan, que contaba con sus propios guardianes y que era una organización capaz de administrar la propiedad. Durante el siglo XIV, en esta ciudad, los principales gremios eran controlados por compañías con una carta real. Más tarde se las llamó “compañías de librea", debido al uso que de ésta hacian sus miembros en ocasiones especiales.

En España, Alfonso $X$ el Sabio fue el primero en establecer ya algunas ordenanzas para los orfebres y broncistas, citándose la de los "concheiros" o fabricantes de veneras, de 1260, por la que se disponía que sólo se podían hacer y vender veneras en la ciudad de Santiago de Compostela. Ahora bien, se puede hablar de cofradias gremiales claras y definidas, con ciertos privilegios, a finales del siglo xIV, especialmente en Cataluña, «pues a la fecha de 3 de mayo de 1381, corresponde el privilegio del Infante D. Juan de Aragón, otorgando al gremio el derecho de nombrar sus miembros el día de San Eloy de cada año, al que sigue otro de 1394 
fijando la ley del oro y otros particulares del oficio, continuando con otras ordenanzas en años subsiguientes" ${ }^{28}$.

Para los soberanos medievales, era de especial importancia la regulación de los trabajos en oro y plata, puesto que tenían que mantener un abastecimiento de suficientes monedas para responder a las necesidades de la población y para garantizar que las monedas de oro y plata en circulación tuviesen un peso y una pureza correctos; de ahí que existiese una fuerte conexión entre el abastecimiento de metal precioso, la acuñación de monedas y la pureza de los objetos en metales preciosos. Así, se prohibía a los orfebres producir artículos de plata de menor calidad que las monedas acuñadas.

Los reyes requerían los servicios de los orfebres para poder efectuar reformas monetarias. En algunos casos, las monedas que circulaban en un pais, por ejemplo, Inglaterra, eran más valiosas que las de otros, por lo que, poco a poco, su calidad se iria deteriorando. En muchos casos, los orfebres actuaban como jueces. Además, el rey, en Inglaterra, necesitaba de los servicios del gremio para supervisar la fabicación de objetos en oro y plata, y los orfebres debían respetar dichas reglas (desde el 1300). Una de esas reglas era que ningún objeto de oro o plata debía estar por debajo de los estándares de oro (19,2 quilates) y plata (esterlina 92,5 por centavo), que marcaba París.

Los guardianes debían aquilatar los artículos de plata y marcarlos con una cabeza de leopardo (tal vez por ser éste el emblema del escudo de armas real inglés). Estos mismos guardianes debían encargarse de aquilatar el oro empleado y vendido en las tiendas que visitaban e inspeccionaban. A lo largo del siglo X.IV y el XV, esta compañía de orfebres ingleses vio incrementar su importancia. De modo que, en el siglo $x \mathrm{~V}$, adoptó su propio escudo de armas. También otras ciudades, como Coloniz, tenían su propio escudo heráldico.

La relación entre los orfebres de una capital y otras ciudades menores solían ser difíciles. Por ejemplo, en Inglaterra, en el siglo XIV, hubo un aumento considerable de orfebres provinciales. Para los orfebres londinenses

Sentenach, Narciso, Bosquejo histórico sobre la orfebreria espaniola. Madrid, Gremio de Joyeros y Plateros de Madrid, 1981, págs. 74-75. DAVII LIEA, CH., Recherches sur IOrfévrerie en Espagne, Paris, A. Quantin, 1879, pág. 97. TINTO I SAI A, Margarida. Els gremis a la Barcelona medieval. Barcelona, Ayuntamiento de Barcelona, 1978, pág. 17. Chuz Valdovinos, José Manuel, Los plateros madrileños. Estudio histórico juridico de su organización corporativa. T. 1. Madrid. 1983. Fernandez. Munoa y Rabasco, Op. cit., "Noticias sobre las cofradias y los gremios de pla teros", págs. 88-90. 
una cuestión importante era controlar a los provinciales. En la Carta de 1327, se ordenaba que los orfebres provinciales enviaran dos delegados a Londres a fin de que se familiarizaran con las marcas de los orfebres de dicha ciudad. Por otro lado, los orfebres londinenses extendieron sus poderes en 1372, de modo que podian visitar ferias provinciales, inspeccionar y aquilatar las piezas.

En el siglo xv, cambiaron el estándar de pureza del oro y los tipos de marcas. Desde 1300, el mínimo estándar para artículos de oro había sido de 19,2 quilates. En 1478, se reduce a 18 quilates y así se mantedria hasta que en 1576 se sube a 22 quilates.

Otra innovación fue el establecimiento, en 1478, de un ciclo de 21 letras de fechas de la $A$ a la $V$ ), que se repetía al llegar a la última letra en modo diferente. Esta idea se originó en 1427 en la ciudad francesa de Montpellier, como consecuencia de una discusión entre los plateros y los acuñadores de monedas reales acerca de trabajar metales inferiores. El objetivo de las letras de fecha era determinar el año y funcionarios responsables de la realización de una pieza de plata. Este sistema se adoptó en París en 1461 y, consiguientemente en Londres en 1478.

Desde mediados del siglo XIV en Londres, los orfebres tenian su propia marca de fabricación, aunque no se solía marcar el trabajo. A finales del siglo Xv, se empezó a hacer un uso más extenso de estas marcas, aunque, en muchos casos resultaba imposible relacionar dichas marcas con los orfebres más célebres. En París, a mediados del siglo xIV, cada orfebre tenía su propia marca y, al parecer, era una costumbre arraigada desde hacía tiempo. Pese a que, según las regulaciones, todas las piezas debian ir marcadas por los "guardianes" y los orfebres, esta regla no se respetaba totalmente en el siglo XIV, de ahí que muchas piezas sólo lleven el sello de uno de éstos. Este uso de marcar las piezas con el sello del orfebre y el de la ciudad o guardián, se había impuesto en Montpellier en 1355, a raíz de unas disputas, y se había convertido en una práctica generalizada.

La precisión o exactitud a la hora de pesar el oro y las gemas era fundamental para el orfebre medieval. La más antigua escala medieval de oro y gemas, que se conserva, perteneció a Hans Harsdorfer y se encuentra en el Germanisches Nationalmuseum. La compañía de orfebres de Londres se encargaba de multar a aquéllos que estafaban a sus clientes. Los casos más frecuentes de fraude eran: placas de metal de base que se hacían pasar por oro o plata. Anillos y hebillas huecos en su interior y que se hacían pasar por sólidos. Piedras falsas, por ejemplo en vidrio o cristal, que se engastaban en oro, o piedras auténticas engastadas en cobre 0 
latón. Coiocar papel de estaño debajo de las piedras para darles mayor lustre.

En cuanto a la pureza del oro, se determinaba con una piedra de toque, que es un pequeño trozo de roca negra de grano fino. Debía de ser lo suficientemente abrasiva como para que se produjese una veta de oro al frotar una muestra del mismo sobre la superficie de la piedra. Esta veta se comparaba entonces con aleaciones de composición conocida. La mayoría de las piedras de toque eran rocas de tipo sedimentario, como tobas volcánicas, pedernales y piedraas sedimentarias.

La Casa Real de la Moneda se encargaba de fijar las medidas estándar para los orfebres, asi como la acuñación estándar del reino. Se celebraban unos juicios o pruebas especiales para determinar si una pieza cumplía los requisitos de calidad necesarios. Por otro lado, existían regulaciones bastante estrictas en lo que se refería a los aprendices de orfebre. Solían referirse a las tarifas a pagar al orfebre, o al gremio o compañía, espacio de tiempo durante el que serviria el aprendiz, despido de él y limitaciones de los aprendices sobre las actividades del gremio.

Se sabe muy poco de la instrucción que recibían y cómo, o del nivel de competencia que se le requería al final de su aprendizaje. En Londres, por ejemplo, un aprendiz debia trabajar en un taller no menos de siete años, salvo que fuera hijo de orfebre y hubiese aprendido el oficio de su padre. El orfebre debía tomar un aprendiz informando de ello a los guardianes y recibiendo su aprobación, y el aprendiz tenía que pagar una prima.

En la mayoría de los gremios europeos - alemanes, franceses, etc.se exigía al aprendiz que realizara una "obra maestra", de modo que se excluyeran nuevos miembros. Esta costumbre, en Inglaterra, se impuso en el siglo xIV. Estas obras solían ser tan elaboradas que resultaban muy costosas y difíciles de vender.

Los miembros solían ser varones. Las mujeres desempeñaron un papel secundario, a veces se las ocupaba en el comercio de joyas. Al parecer, una especialidad que les era propia era el pulido. Además, si su esposo moría, en ciertos casos, se hacían cargo del negocio. De cualquier modo, es probable que se ocupasen de la tienda en ausencia de su marido.

En cuanto a la vida social de los orfebres, como tal cuerpo, destacaba la celebración del día de su patrón —en Inglaterra, San Dunstan, el 19 de mayo; día en que se cerraban estos negocios, se reunian todos, etc. Eran fiestas alegres y grandes celebraciones, con banquetes, etc. 
La riqueza e importancia de los orfebres los llevó a ocupar un lugar preeminente en las procesiones y desfiies de las ciudades. En esos casos, los orfebres solian lucir ricas y lujosas vestimentas, con adornos en oro y plata, como se observa en la pintura del desfile de la coronación de Eduardo $\mathrm{VI}$, en 1547 , en la que se pueden ver representadas las tiendas de los joyeros en Cheapside, Londres (v. fig. 14).

Hubo orfebres que aprendieron el oficio en su ciudad natal, en ella trabajaron, progresaron y murieron. Otros, en cambio, prefirieron cambiar de ciudad o pais y viajar. Londres y París fueron dos centros que atrajeron a muchos orfebres de otras provincias y paises. A finales del siglo XIV, joyeros, como Jean de Lille, Hans Karast -orfebre del duque Luis de Orléans-, o Claus de Fribourg, se establecieron en París y en dicha ciudad prosperaron. A veces, se daban casos de gran rivalidad entre los orfebres oriundos de un lugar, por ejemplo Londres, y los emigrantes.

No se sabe con seguridad cómo un joyero llegaba a un diseño final para las piezas que iba a realizar. En muchos casos, eran anillos, broches, etc., que debian basarse en in modelo sencillo y repetitivo. Si se trataba de piezas más elaboradas, sobre todo si se hacía contrato, se mencionaba, a veces, un dibujo.

En el siglo XV, existía en Alemania una relación muy estrecha entre grabadores y orfebres, ya que se grababa mucho sobre plata. El arte de grabar a partir de placas grabadas se originó en los talleres de orfebrería del sur de Alemania, entre 1430 y 1470 , los grabadores fueron principalmente joyeros. Por ejemplo, Schongaüer o Albrecht Dürer -1471-1528-, hijo de un orfebre, que realizó numerosos diseños para joyas que están influidas por el estilo renacentista italiano (fig. 15).

\section{f) Los contratos}

Los joyeros no solían emprender la fabricación de objetos sin un contrato específico, puesto que implicaban el uso de materiales preciosos. Si bien, los objetos que producian cotidianamente -broches, anillos, bandejas y platos de plata-, se iban acumulando en las tiendas para ser vendidos. Cada joyero, según la época y lugar, organizaba la producción de un modo. Se conservan aún algunos contratos específicos para la fabricación de ciertos objetos particulares.

En los contratos ingleses, se puede apreciar cómo los encargos caros de las provincias se hacían a los orfebres londinenses. Los joyeros se agrupaban en las capitales en determinadas áreas. Por ejemplo, en París, 

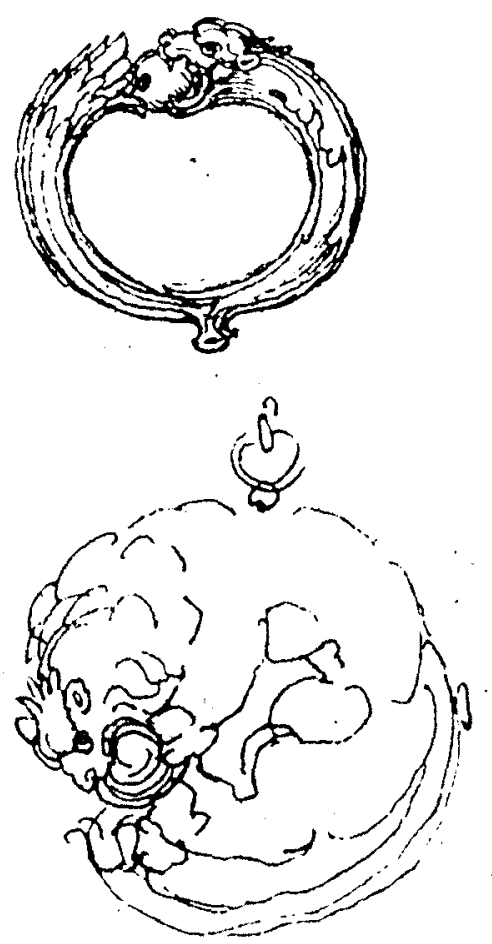

Fig. 15. Dibujo de joya. Alberto Durero. 1471-1528.

el centro del comercio de los orfebres era el Puente principal sobre el Sena. En Colonia se concentraban en torno a la catedral. En Lübeck junto a la plaza del mercado, y, en Amberes había una "calle de la orfebrería» cerca del ayuntamiento. En Madrid, las tiendas de plateros y joyeros se concentraban en la calle Mayor. En cualquier caso, los orfebres se instalaban en las zonas frecuentadas por la clientela rica y selecta.

Algunos orfebres trabajaban para las cortes de reyes o ricos nobles, $y$, por ello, aparecen citados sus nombres en cuentas e inventarios. Con frecuencia, las obras más sencillas o de menor atractivo de estos joyeros, fueron fundidas para convertirse en nuevas piezas. Los clientes más ricos no dudaban en pedir a los orfebres que los visitaran en sus casas y les mostraran sus mercancías. Otros clientes menos ilustres debian conformarse con visitar ellos mismos las tiendas.

Las características de estos comercios las conocemos por: descripciones escritas; inventarios de las posesiones de los orfebres; pinturas y re- 
presentaciones de ellas. A principios del siglo XIV, las típicas tiendas de Cheapside, zona donde se concentraban las joyerías londinenses, eran bastante pequeñas - unos $2 \mathrm{~m}$. de ancho y unos $3 \mathrm{~m}$. de profundidad-. Solían tener una ventana o escaparate que se abría a la calle, con una puerta al lado y solían servir también de taller. La trastienda se usaba como almacén, utilizándose para ello cofres y cajas. Este tipo de tienda era el más común en Europa. Podían tener más habitaciones en el piso superior, donde, o se almacenaban objetos o vivía el joyero.

A través de los inventarios de los joyeros, se ha podido saber qué objetos almacenaban, qué piedras poseían y el valor de estas piezas. El pintor flamenco Petrus Christus (fig. 16), en su lienzo de El joyero y los prometidos, de 1449, muestra la compra de un anillo de boda o de compromiso. Al fondo, se pueden apreciar los objetos que se exponen en estantes y cajitas: anillos... El joyero con una balanza, se prepara para pesar un anillo, peso que determinará su precio. Junto a ello hay una pila de monedas de oro de Mainz (Alemania), de Inglaterra y del Ducado de Borgoña, muestra del intercambio internacional de monedas de oro y del comercio entre orfebres de distintas nacionalidades. Algunas de las piezas, que se representan en éste y otros cuadros, nos han llegado y se pueden admirar ahora en tesoros y museos del mundo entero.

\section{DEL RENACIMIENTO A LA REVOLUCIÓN FRANCESA}

Los gremios medievales y los del Renacimiento se transformarían en colegios, a comienzos del siglo XVII. El objetivo fundamental del gremio siguió siendo el control de un mercado local propio: control de la calidad de los productos mediante el cual se evitaba la competencia entre productores; control sobre la oferta y la productividad; control, en definitiva, sobre la mano de obra.

Estas necesidades determinaban las principales funciones del aparato institucional del gremio y, en consecuencia, los principales cometidos de sus cargos directivos. Tales cargos, según Coornaert, son, ante todo, expertos, encargados del control técnico, de la policia profesional y de uria cierta jurisdicción ${ }^{29}$. Para el orfebre, era importante ser nombrado cargo directivo del gremio, pues le daba un prestigio social, aunque la remuneración económica, que recibía por ello, no fuese notable.

29 CoOhnaert, Emile, Les Corporations en France. Avant 1789, Paris, 1968, pág. 2. 


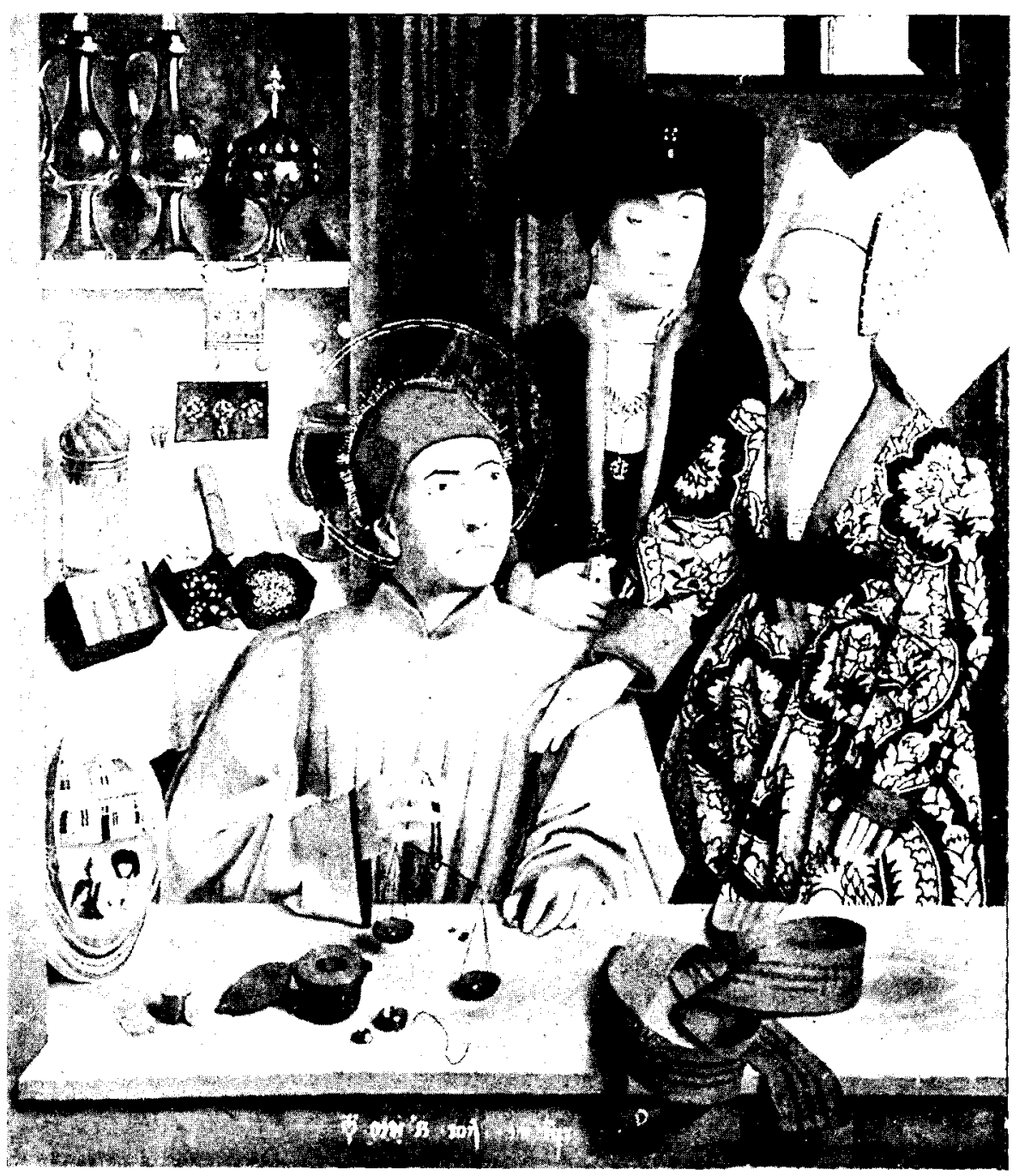

Fig. 16. Petrus Christus (?-1472). San Eloy en su trabajo. Colección particular, Nueva York.

De la época renacentista, conocemos a diferentes artistas joyeros, citados por Benvenuto Cellini en su Tratado de Orfebrería ${ }^{30}$-obra paralela a la ya comentada del monje Teófilo-. Cada uno de los artistas citados

Op. cit, págs. $23-30$. 
cumple los requisitos que Cellini exige: "prestos para el buen hacer» y especializado en uno de los ocho procedimientos de trabajo que tiene este bello arte para llegar a una cierta perfección. Así, Lorenzo Ghiberti es alabado por la fundición; Antonio di Pollaiolo, por sus excelentes dibujos; Piero di Nino dedicado a la filigrana; Donatello, Brunellesco, Verrochio, Durero,... como consumados orfebres y joyeros.

Amén de estas figuras, hemos de destacar las obras y escritos de Cellini, quien, habiendo alcanzado tanta perfección en el arte de la joyería $y$, no habiendo ningún manual para estudio y formación de otros artistas, decidió verter sus conocimientos en el citado Tratado. En él, estudia los metales, procesos y técnicas como base fundamental para llegar a dominar este arte.

Juan de Arphe, con su Quilatador de la plata, oro y piedras, impreso en Valladolid en 1572 (fig. 17), realiza en España una tarea similar.

Una innovación técnica, que introdujo el Renacimiento, es la del repujado de relieve cada vez más pronunciado, técnica que evolucionó, en los siglos siguientes, hacia una concepción pictórica que sustituyó las tradicionales figuras individuales por plafones narrativos de escenas. Además, paulatinamente, se sustituirá la filigrana en piezas de plata por el torneado de mayor consistencia.

El esmalte, que hasta entonces se había empleado profusamente, pierde protagonismo y sólo se aplica como motivo decorativo auxiliar, en pequeños elementos de colores transparentes, medallones pintados o nielados, variante que consiste en la incrustación sobre metal pulido de un color negro, formado por una fusión de cobre, plata, plomo, bórax, azufre y sal amoniacada.

En la orfebrería de tipo religioso, se mantienen elementos decorativos del Gótico, aunque se introducen motivos renacentistas, inspirados en los grabados importados de Italia: columnas de tipo romano, hojas de acanto, grutescos, cartelas y guirnaldas. Se siguen produciendo cruces, relicarios, custodias, etc., piezas en las que se introducen características arquitectónicas, como la adaptación del primitivo sagrario turriforme, en forma de torre renacentista.

No obstante, esta orfebrería halla un modo de expresión verdaderamente creativo y artístico en la joyeria civil, con la realización de joyas y piezas de vajilla, al servicio de las modas imperantes y no tan ligado a la tradición, como lo está en el ámbito religioso.

De esta época, data la publicación de libros que recogían modelos o diseños de joyas. Producidas por joyeros y grabadores célebres, estas obras 


\section{Q V I L A T A D O R}

DELA PLATA, ORO, Y PIEDRAS,

COMPVESTO POR IOAN EARPFE de Villafuñe: nacurel de Leó. tezino de Valladalid.

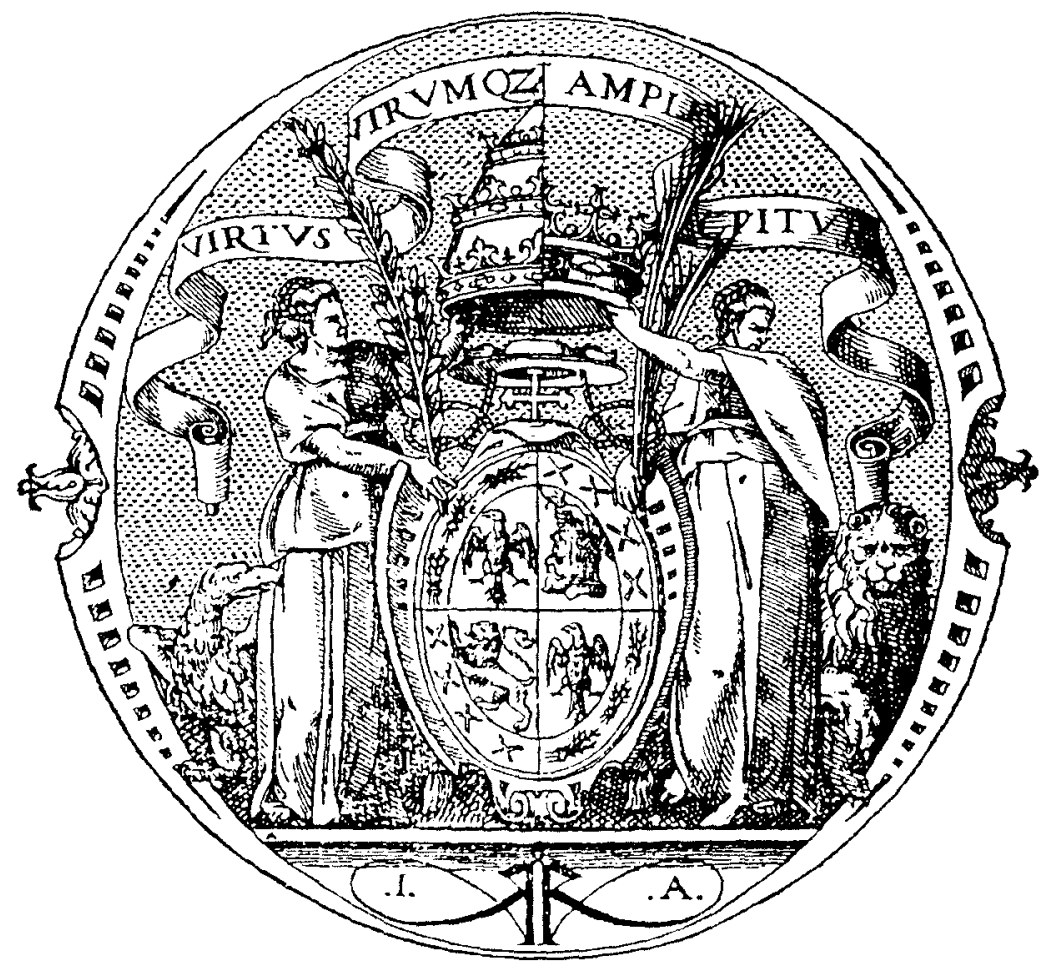

Impreilo en Vailadolid, por Alonfo y Diego Fernädez de Cordoua, Impreifores de fu Mageftad. Año M. D. LXXII.

CON PRIVILLEGIO.

Fig. 17. Portada del Tratado de Juan de Arfe.

recopilaban diseños para todo tipo de joyas que, al circular por toda Europa Occidental, eran adoptados e imitados por artesanos de menor importancia ${ }^{31}$, contribuyendo a la unificación del estilo en todo el conti-

31 BLACK, Anderson J., A History of Jewelry, Londres-New York, Park Lane, 1974, págs. 151 y ss. 

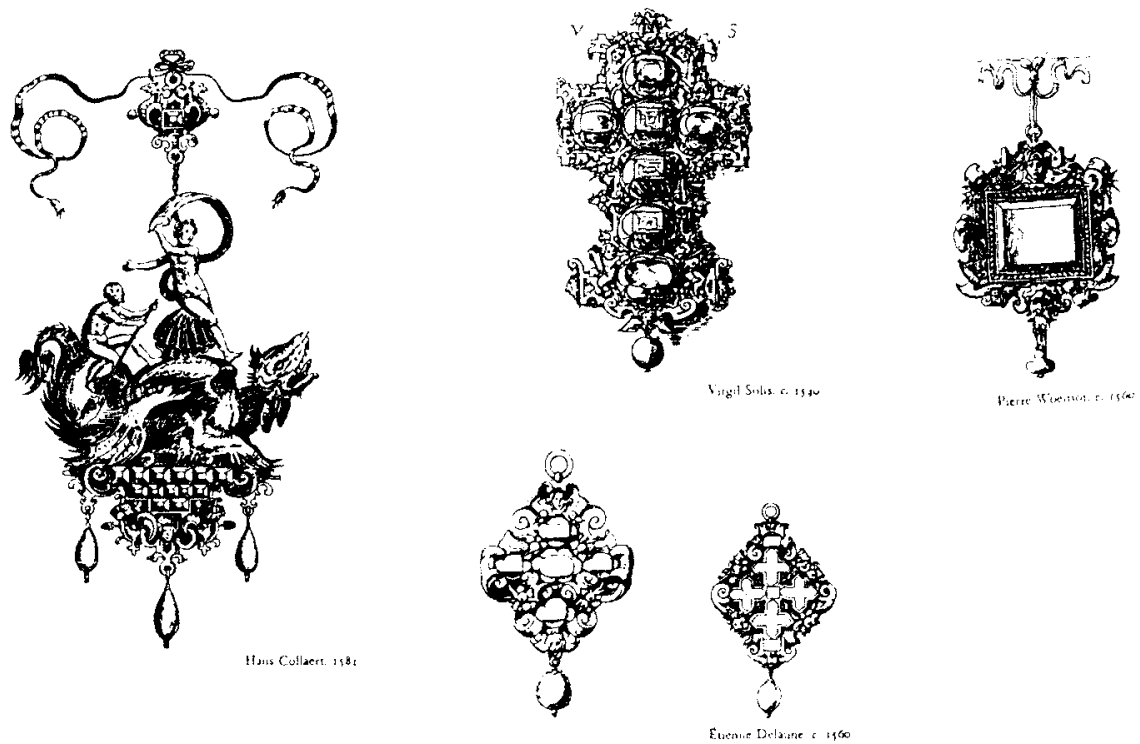

Fig. 18. Dibujos de joyas de Hans Collaert, Virgilio Solis, Étienne Delaune.

nente. Entre éstos, podemos citar los de Hans Collaert, Erasmus Hornick, René Boyvin, Delaune y otros ${ }^{32}$ (fig. 18).

Los motivos con que se decoraban estas piezas, se basaban, en una primera etapa, en la tradicional estilización de troncos y follajes góticos, a los que frecuentemente se incorporan flores y formas animales (capullos, lirios, delfines), o bien, una interpretación realista de la flora, lo cual origina dibujos formados por un tema central, enmarcado por tallos ondulantes y brotes serpenteantes laterales, típicos de los grutescos renacentistas. Los temas de la segunda etapa no tienen ningún punto de contacto con estos motivos y forman unos complicados conjuntos que consisten en flores y frutos, cartelas curvadas y contracurvadas, rodeando las monturas con piedras preciosas, gemas y perlas, que constituyen el principal valor de estas joyas ${ }^{33}$.

A finales del siglo XVI y a lo largo del siglo XVII, fueron frecuentes las representaciones de seres fantásticos y mitológicos, como caballos alados,

32 A Hans Collaert se debe la serie de diez láminas Monilium Bullarum inauriumque artificiosissimae icones, de 1581. Le Livre de bijouterie de rené Boyvin, d'Angers.

33 Dalmases, Nuria de, op. cit., págs. 146 y ss 
sirenas, sátiros, centauros, tritones, sagitarios, camellos y otros animales. Por lo que se refiere a los temas animales, es notable la influencia de las joyas americanas, en particular de las precolombinas, pero tratadas siempre a la manera europea.

Podemos observar un cambio en la decoración de las joyas, a finales del siglo XVII, que se caracteriza por la riqueza desmesurada y la sobreabundante ornamentación a base de trenzas, guirnaldas, foliaciones rizadas y onduladas, conchas y rocallas. Estos temarios eminentemente barrocos y rococós fueron expresados con un perfecto dominio de las técnicas del repujado y cincelado.

En el Renacimiento, la orfebrería alcanza un gran apogeo, al conseguir una gran perfección técnica, y goza de un lugar preferente en la vida civil y religiosa. La llegada de metales preciosos, procedentes del Nuevo Mundo, estimula también el celo de los artistas y la clientela. Los reyes se constituyen en mecenas y, entre sus protegidos, se encuentran los joyeros, procedentes en muchos casos de Italia, Flandes y Alemania, por ser éstos los de mayor fama y renombre.

En ese sentido, habría que señalar que el joyero tendía a establecer su taller en aquellos lugares donde pudiese encontrar la fácil protección de un mecenas y donde pudiera dar salida a sus productos. Por este motivo, fueron numerosos los joyeros de origen flamenco que trabajaron para las distintas cortes europeas, rivalizando con los italianos y, pronto, con los franceses. El joyero se adaptaba a las circunstancias, a los gustos de sus protectores y a los medios del país que los acogía ${ }^{34}$.

La profesión de los orfebres era una profesión jurada, que se agrupaba, como sabemos, en cofradias o gremios. En Francia, por ejemplo, en 1543, se impuso a los orfebres un régimen corporativo, medida que proporcionó al tesoro real la ocasión de percibir unos ingresos importantes por todos los cargos y oficios que se crearon: guardianes, controladores, arrendatarios de los derechos de marca...

Como en la Edad Media, los orfebres siguen gozando de una alta consideración y de unos ciertos privilegios, hecho que se explica por los materiales con los que trabajaban y por sus reconocidas honestidad y probidad. De hecho, habian sido y continuaron siendo una aristocracia en el mundo del trabajo. Algunas familias de orfebres ilustres, en las que se había transmitido un cargo de padre a hijo, proporcionaron también fun-

34 LANI I.JF R, Jean ef PINI, Marie-Anne, Cinq Siècles de Joaillerie en Occident, Suiza, Office du Livre, 1971. 


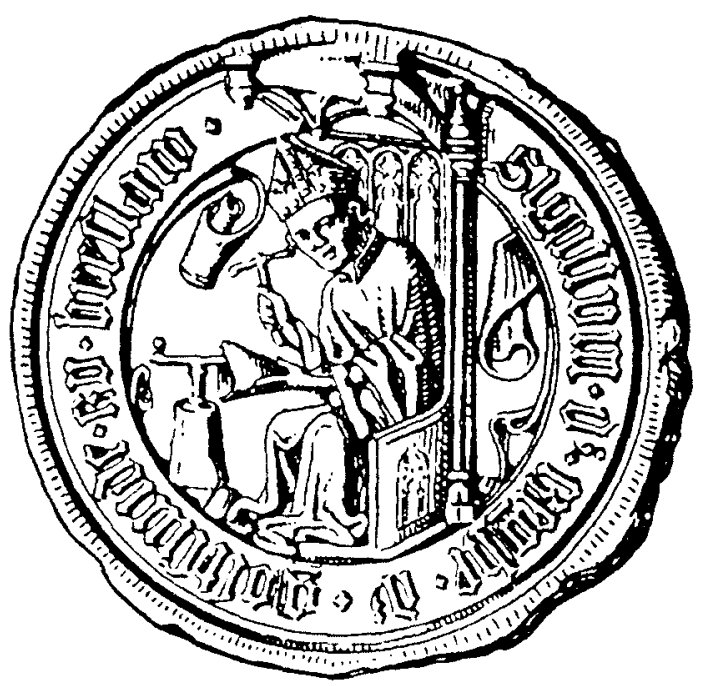

Fig. 19. Dibujo del punzón del joyero de Breslau, representando a San Eloy en el trabajo. S. $x$ V.

cionarios civiles del más alto rango. Además, no debemos olvidar que, en los comienzos del Renacimiento, en los talleres de orfebres, se formó a pintores y escultores, como fue el caso del maestro de Leonardo de Vinci, Verrochio, quien se jactaba de su título de "buen orfebre» ${ }^{35}$.

Los orfebres seguian agrupándose en ciertas zonas de las ciudades. Sus tiendas, muy sencillas, estaban abiertas a todos los transeúntes. Los clientes y curiosos podian penetrar en el taller, ya que no se permitía que hubiera secreto en su actividad. De día e incluso de noche, se ejercía un control severo sobre estos talleres, comprobándose el peso de las piezas, pureza de los metales, autenticidad de las piedras y empleo de los materiales de adorno, reglamentándose los procesos de soldadura e imponiéndose el uso mesurado de los esmaltes. Aquél que contraviniese estas leyes, era juzgado severamente.

El orfebre seguía marcando sus obras con su punzón (fig. 19), pero, además, en el Renacimiento, se impone el uso de añadir las iniciales al emblema personal. La pieza iba también marcada con el emblema de la ciudad a la que perteneciese ese taller, atestiguando que se habia sometido a un control fiscal.

\footnotetext{
35 Vedres, N. G., "La Renaissance et les Temps modernes", L Orfévrerie. La Joaillerie, París. Editions du Chêne, 1942, págs. 27-43.
} 
No era tan sencillo llegar a ser un orfebre rico y poderoso, ya que, primero, había que pasar por un aprendizaje de unos ocho años, período durante el que no se percibía ningún salario, compartiendo comida y alojamiento con el patrón o maestro. Este período de aprendizaje era menor si el aprendiz era hijo d de un joyero. Una vez terminado este aprendizaje, el futuro orfebre debia realizar una obra maestra, con la que demostraba su habilidad manual y su talento inventivo. Además, debía pagar una fianza, para cubrir fraudes en los que pudiera incurrir.

Finalmente, podía ingresar en la corporación, tras presentar su punzón, para que se le reconociera, y podía empezar a trabajar, ayudado por otros aprendices, miembros de su familia o de las de otros cofrades. Era frecuente que los orfebres de fama trabajasen para la corte real de su país e incluso de otros.

En todas partes, se impone el mismo gusto por el ornamento precioso y coloreado; en todas partes, la moda de las joyas de estilo "flamenco" sucede a las de estilo italiano. En casi todos los países, a fines del siglo XVI, la joya tiende a hacerse más pesada, a sobrecargarse, a buscar un realismo, que parece estar en contradicción con el material empleado, para volver en seguida a una mayor sencillez, casi abstracción.

La joyería renacentista evoluciona en el Barroco hacia un enriquecimiento de formas y materiales. Se exageran los adornos y las formas de un modo innovador, que influye a otras artes en lugar de imitarlas. Los orfebres, en ese momento, poseían tal perfección, facilidad y agilidad de manos, y en su temperamento de artistas, tal imaginación y abundancia de ideas, que se orientaron inevitablemente hacia formas rebuscadas en exceso, cuyo estilo rococó fue su máxima expresión.

La evolución de la creación joyera se debe a una mejora técnica: se aprende a tallar las piedras, dándoles un brillo y una belleza hasta entonces desconocidos. Además, se montan las piedras de manera más ligera y casi invisible.

Los artistas siguen viajando tanto como antes y, salvo España, que permanece cerrada a nuevas influencias, todos los paises producen joyas del mismo tipo, inspiradas en los dibujos más célebres, ya que se publican "albumes de dibujos de joyas", siendo quizá los más interesantes los de París ${ }^{36}$, aunque los artistas alemanes, ingleses e italianos los editan igualmente (fig. 20).

36. Gilles de Légaré. Duflos. Maria y la misma Enciclopedia (vol. 8, 208-25), pág. 199. 


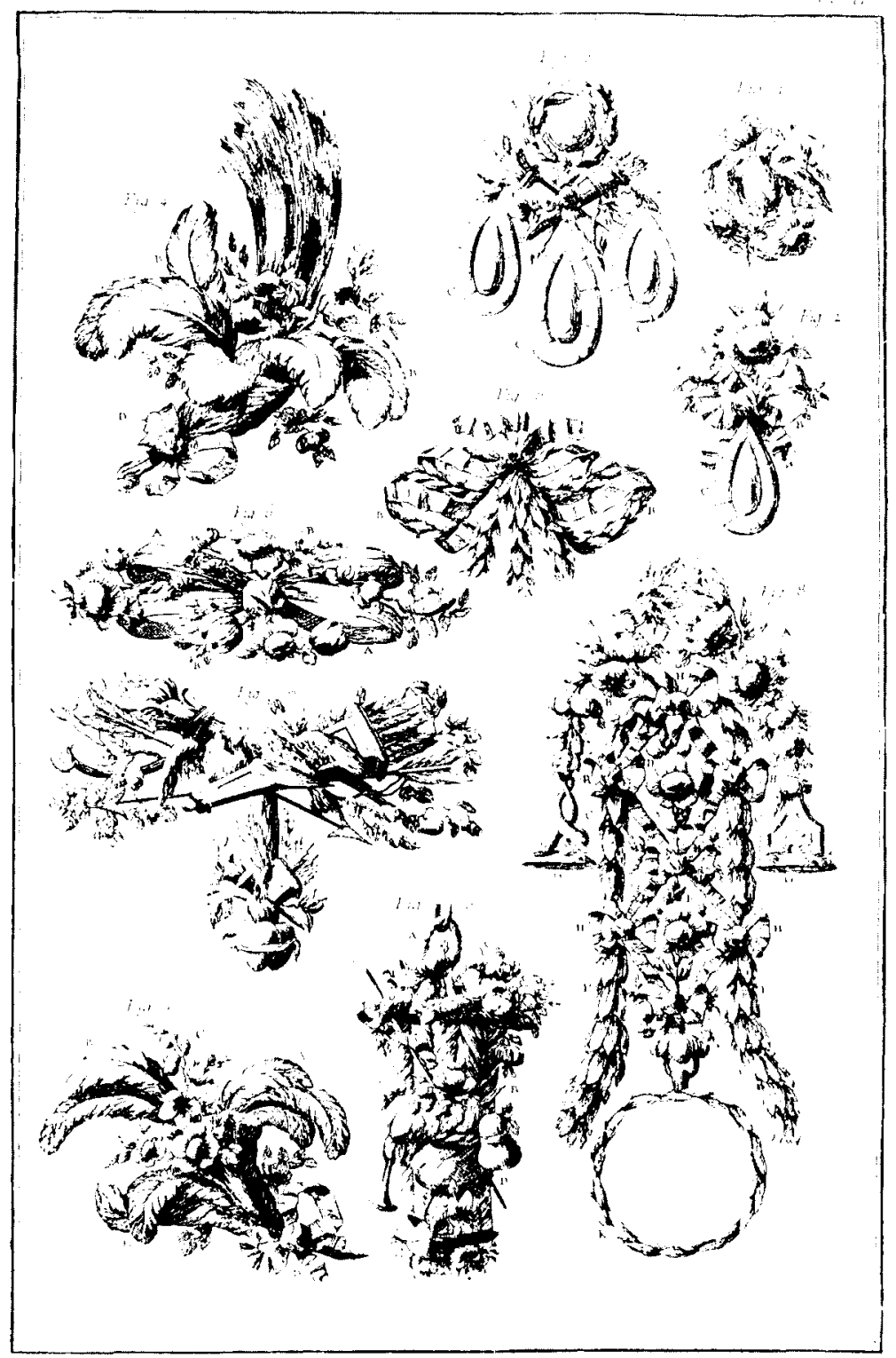

Fig. 20. A) Diseños de Legaré, Aaugustin Duflos, Pouget o Maria se recogen en la citada Enciclopedia francesa. Reproducimos alguno como ejemplo. 


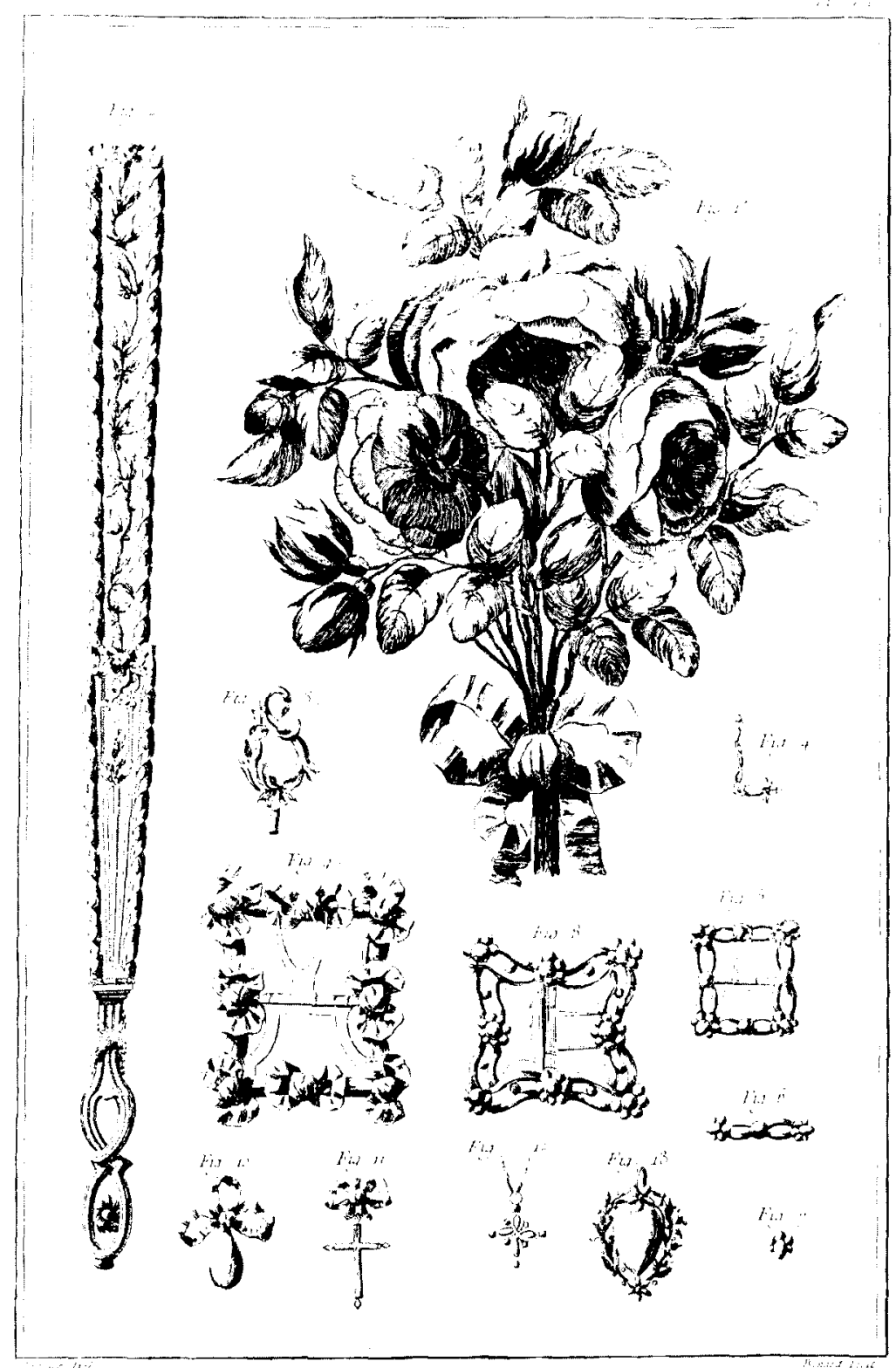

(?)

Fig. 20. B). 
Desde mediados del siglo XVIII, se observan los primeros movimientos de reacción contra el Barroco, salvo en España, donde los joyeros se alejan de su pasado, para adoptar el más puro estilo rococó, produciendo piezas de joyeria que pueden clasificarse entre las más interesantes de la época.

Al gusto del Rococó, que tanto plugo a la Corte, le sucede una preferencia por los motivos griegos. Es el período neoclásico, a cuya influencia también sucumben los orfebres. Las grandes piezas masivas anteriores se ven sustituidas por "pequeñas maravillas" - como, tabaqueras, bomboneras, objetos de tocador, teteras y chocolateras, y otras miniaturas ${ }^{37}$. Pronto, los joyeros asimilan las nuevas aleaciones e imitación de piedras preciosas: uso del oro de Mannheim, similor, estrás, chapado... Al mismo tiempo, aparecen nuevas herramientas mecánicas, que aligeran el trabajo del artesano: torno de pie, martinetes para el repujado y el estampado. Pero la innovación más importante es la creación de un nuevo oficio, el de decorador de orfebrería. Se trata de dibujantes especializados en la composición de motivos ornamentales a la moda, por lo general. El orfebre acepta con espontaneidad el diseño que se le propone, y abandona el papel de artista, que había tenido hasta entonces, como creador de sus propios diseños.

\section{DE LA REVOLUCIÓN A NUESTROS DIAS}

Amenazada por la intervención de materiales nuevos y menos nobles, por los daños del maquinismo naciente, por una cierta decadencia del gusto, la orfebrería se encuentra en el umbral de la Revolución. De ahí que, en el siglo XIX, se eliminen las corporaciones, salvo la de los orfebres, cuyo oficio debía someterse por fuerza a una reglamentación. Ahora bien, la orfebrería no se sustrajo a los cambios que hubo en la organización del trabajo y en las fuentes de creación.

Hasta entonces, los joyeros habían gozado de una seguridad en la difusión de su producción hacia las cortes y clases altas de los siglos anteriores. Bruscamente, cambiaron las cosas y el artista se vio forzado a halagar los gustos de una burguesía mediocre e incluso del mismo pueblo, y lo que es más grave, el joyero se vio despojado de su seguridad, tradición y privilegios profesionales, que con tanta dificultad y méritos había alcanzado,

\footnotetext{
37 De las cuales aparecen reproducciones en la Enciclopedia Francesa, op. cit., planchas III y IV, y láminas III, IV y V.
} 
para convertirse en comerciante. Basta con ser descendiente de un joyero hábil y haber sabido conservar su patrimonio comercial, para recibir el título de joyero, aunque no se debe hacer de esta afirmación una generalidad.

Los talleres de joyeros que, desde la Edad Media hasta el Renacimiento, habian sido cunas del arte, en los que pintores y escultores aprendían la técnica, la ciencia de las proporciones y de la belleza, en general, en nuestro días, se convierten en empresas comerciales.

En esta época, se puede hablar de una decadencia del arte de los orfebres en toda Europa, salvo en Rusia, que, hostil al cambio, se aisla y conserva por algunos decenios aún sus tradiciones de fasto y de lujo. Esta decadencia se refleja en el hecho de que los orfebres se limiten a depurar las formas y a cambiar los elementos decorativos por temas neoclásicos y egipcios. Las joyas se caracterizan por un estilo pomposo, cuyo único atractivo es la armonía de proporciones y simetría, con abundantes elementos alegóricos, como cabezas de esfinge y pájaros, grifos, motivos bucólicos y guirnaldas. Parece tanto más curioso cuanto que, en el trabajo de metales menos nobles, como el estaño y el cobre, se hallan obras de una elegancia y una sobriedad encantadoras.

La industrialización de la orfebrería se acentuó durante el siglo xIX, y la auténtica revolución industrial, que, a mediados de siglo, generalizó la fabricación industrial de dicho arte, fue el descubrimiento del dorado y plateado por medio de la galvanoplastia, que permitió recubrir cualquier sólido con una capa metálica por la acción de una corriente eléctrica. La industrialización provocó una decadencia de la orfebrería religiosa, en favor de la civil, debido al auge de la burguesia. Las joyas se convierten en un bien más asequible para las clases menos adineradas.

A comienzos del siglo $x \mid x$, se empieza a registrar la sensibilidad y la melancolia romántica, que se traduce en una creación de joyas intimas - como guardapelos- y en una simbolización de las piedras -el zafiro, por ejemplo, es mensaje de felicidad celestial, las esmeraldas son esperanza y los rubíes, gozos de amor. La joya intima es pues la novedad, se torna suave y ondulada, y esta expresión externa del sentimiento se traduce en obras de más cuidada ejecución y complejidad. A los ornamentos griegos, romanos, etruscos, egipcios, se añaden los de otros estilos orientales: musulmanes, hindúes, chinos y japoneses; así como la evocación de estilos folklóricos y pasados: bizantino, románico, gótico...

Desde el punto de vista técnico, la joyería alcanza una gran calidad, sobre todo en lo que se refiere al engaste de piedras, cuyo uso se incrementa, por la llegada de piedras preciosas de menor valor, procedentes de Méjico y de Brasil -topacios, amatistas, aguamarinas...-, con las que se 
elaboran joyas importantes y relativamente poco costosas. Vuelve la moda de los camafeos y de las joyas de luto. La clientela se apasiona por la joya en acero, pulido y facetado, lo cual abarata también su precio.

Cambia el concepto de joya, no clasificándolas ya por su dibujo o estilo, sino por la adaptación a las ocasiones en que se la lucirá. En la corte como en la ciudad, los vestidos y costumbres se uniformizan, por lo que se puede hablar más que nunca de un arte internacional de la joyería.

Bajo la Restauración y el reinado de Louis-Philippe, la jornada del obrero era de once horas y media completas. En verano, comenzaba a las seis, almorzaba en el taller a las diez (en la media hora concedida). De cuatro a cinco salía del taller para ir a cenar y volvía a trabajar hasta las siete. En invierno la jornada comenzaba a las ocho de la mañana y terminaba a las nueve de la tarde. En momentos de apremio y mucho trabajo, el obrero hacía horas extra por la misma remuneración ordinaria.

Tras la Revolución de 1848, la jornada se reduce a diez horas. Los obreros ya no almuerzan en el taller y tienen una hora entera para ello, que solía hacerse a las once. Este nuevo horario era más saludable por permitirles cambio de ambiente y movimiento, ya que el taller contenía vapores malsanos procedentes de las sustancias para el tratamiento del oro.

Se seguían formando Corporaciones con sus propias prerrogativas y Fiestas simbólicas, como, por ejemplo, la recepción de un obrero que acaba de terminar su periodo de aprendizaje.

Se podría hablar de distintas ramas o especialidades del oficio de joyero: en primer lugar, los joyeros-engastadores (que fabrican joyas en las que hay que engastar piedras preciosas), calificados como fantasistas cuando crean nuevas formas para las joyas, que se adaptan a los caprichos de la moda. Los vaciadores ("creusiste") que hacen toda la joyería hueca (pendientes, broches, anillos, botones de camisa, cruces, brazaletes, etc.). Se da el nombre específico de "cadenista" a los que fabrican cadenas de todo tipo - de los chalecos, de cuello, etc.Chapeador o chapista de oro (oro sobre bronce u otro metal inferior); bisutero, que realiza joyería de imitación en crisócalo o cobre dorado, que procede originariamente de Italia, y que también puede imitar piedras preciosas. Estos mismos procedimientos se pueden aplicar a la plata ${ }^{38}$. Otras joyerías de las que podriamos hablar son: la de acero, la concha o carey y el marfil.

38 También se utilizó aluminio blanco — como la plata, pero más ligero-y bronce de aluminio - casi tan brillante como el oro-. 
En la segunda mitad del siglo XIX, la moda evoluciona hacia un gusto por los motivos abstractos o naturalistas y las monturas se hacen más ligeras e invisibles. Se celebran exposiciones universales, que emulan el trabajo de los joyeros que participan en ellas. La joyería muestra más iniciativa e imaginación que otras industrias del arte, a pesar de los materiales empleados.

Aparece en escena la nueva joyería procedente de Estados Unidos, país que cuenta con una rica clientela, lo que marcará cada vez más las modas venideras.

A finales del siglo xIx, conviene destacar un hecho social en la historia de los joyeros: la desaparición de su gremio. La organización gremial había iniciado su decadencia a principios de siglo. En 1837, por ejemplo, se suprime el Colegio de Plateros de Sevilla, aunque los miembros de la plateria sevillana siguen realizando exámenes de maestría hasta 1867, fecha en que se podría decir que desaparece el gremio, si bien los plateros seguirán agrupándose en hermandades religiosas en torno a su patrón, San Eligio, hasta comienzos de este siglo, en que desaparecerán totalmente. En Cataluña, la asociación se extinguió totalmente entre los años 1870 y $1873^{39}$.

El siglo XIX se despide con un movimiento de corta duración pero gran importancia: el Art Nouveau. Multitud de artistas se dedican a la creación de joyas, provocando una renovación de la estética. El dibujo no es el único aspecto que les interesa, buscan los materiales, piedras y metales por ellos mismos, realizan numerosas experiencias técnicas, que llevan a un progreso de un gran número de ellas; el arte de esmaltar, por ejemplo, conoce un cierto renacimiento, y algunos artistas logran grandes proezas en el mismo. Este interés por los metales, sean o no preciosos, puede explicarse por razones de tipo científico, como el progreso de la física y la química, los descubrimientos y los estudios más avanzados gracias a los nuevos aparatos, que revelan en piedras incluso modestas, secretos y riquezas hasta entonces insospechados. De ahi que el artista quiera demostrar que un objeto puede ser bello, sin tener por qué ser costoso. Es un período en que se revalorizará más la figura del artista, por lo que se paga más su firma que las piedras preciosas que comporte la joya. Este renacimiento del artesanado no puede mantenerse en el anonimato, por lo que hace que todo objeto, incluso los utilitarios, sea una obra de arte identificable.

Sanz Serrano, María Jesús, El gremio de plateros sevillano 1344-1867. Sevilla, Publicaciones de la Universidad de Sevilia, 1991, pág. 11 y 165-178. DALMASES, Nuria de, op. cit, págs. $176-177$. 
Las joyas están especialmente destinadas a la mujer, o más bien a un ideal de mujer. Más que nunca la flora y la fauna aparecen como motivo decorativo en la joya, y también la mujer tiene un papel importante en la decoración: mujer-flor, mujer-libélula, o sencillamente, mujer que nada o vuela en un leve torbellino de líneas sinuosas.

Ciertas corrientes del Art Nouveau han contribuido a la creación de nuestro estilo actual, desprendiendo el arte decorativo de las fórmulas tradicionales anquilosadas y revalorizando las cualidades inventivas del artista.

Al desaparecer los gremios y las corporaciones de joyeros, la figura de este artesano pierde importancia y su definición queda difusa y oscurecida ${ }^{40}$. En parte se debe a la eclosión de grandes artistas, como pintores y escultores, que han ensayado también este género: Georges Braque, Salvador Dalí, Julio González ${ }^{41}$, Durrio, Lalique, Alfons Mucha, Masriera... Al desarrollar esta faceta paralelamente a su actividad tradicional, han contribuido a que la figura del joyero sea poco definida.

El aspecto más destacado de la joyería de nuestro siglo es que gira siempre en torno a la figura de la mujer y que tiene un carácter funcional y utilitario ${ }^{42}$. El siglo anterior le habia legado otros gustos: el interés por las artes populares y primitivas, revelando el encanto de los objetos espontáneos, sin pulir, y de la materia bruta, dándose menor importancia al acabado de las obras.

Se podría hablar de varios periodos. El primero abarca de 1910 a 1925, y sólo admitía modelos y obras de nueva inspiración y originalidad reales, excluyendo toda copia, inspiración o imitación de los estilos antiguos o del pasado. A partir de 1929, la joyería busca una ligereza, de la que se había alejado anteriormente, y da menos importancia al color. La Segunda Guerra Mundial impone, en casi todos los países, una ralentización considerable de la producción, seguida por una reacción comprensible: tras años de privación, se busca la abundancia y, durante algunos años, se producirán joyas pesadas, geométricas, que exigen gran cantidad de oro. Sin embargo, la joyería poco a poco logra una mayor ligereza y armonía, que son las principales características de nuestras joyas actuales.

Fougife t, Georges, "La Bijouterie et la Joaillerie modernes", LOrfévrerie. La Joaillerie, op. cit, págs. 89-101

Hucittes. Graham. 5000 ans de Joaillerie, París, Calmann-Lévy, 1973, págs. 121-171.

LANI. II $\%$, Jean, op. cit., "Le XX siècle", págs. 225-295. 
Qué mejor definición del joyero, para terminar, que la que da José María de Heredia en el cuarteto dirigido al Barón Charles Davillier: «Mejor que ningún maestro inscrito en el libro de maestria,/ Ya se llame Ruiz, Arfe, Eximenis, Becerril,/ He engastado el rubi, la perla y el berilo,/ Torcido el asa de un jarrón y martilleado su friso" ${ }^{43}$. 